
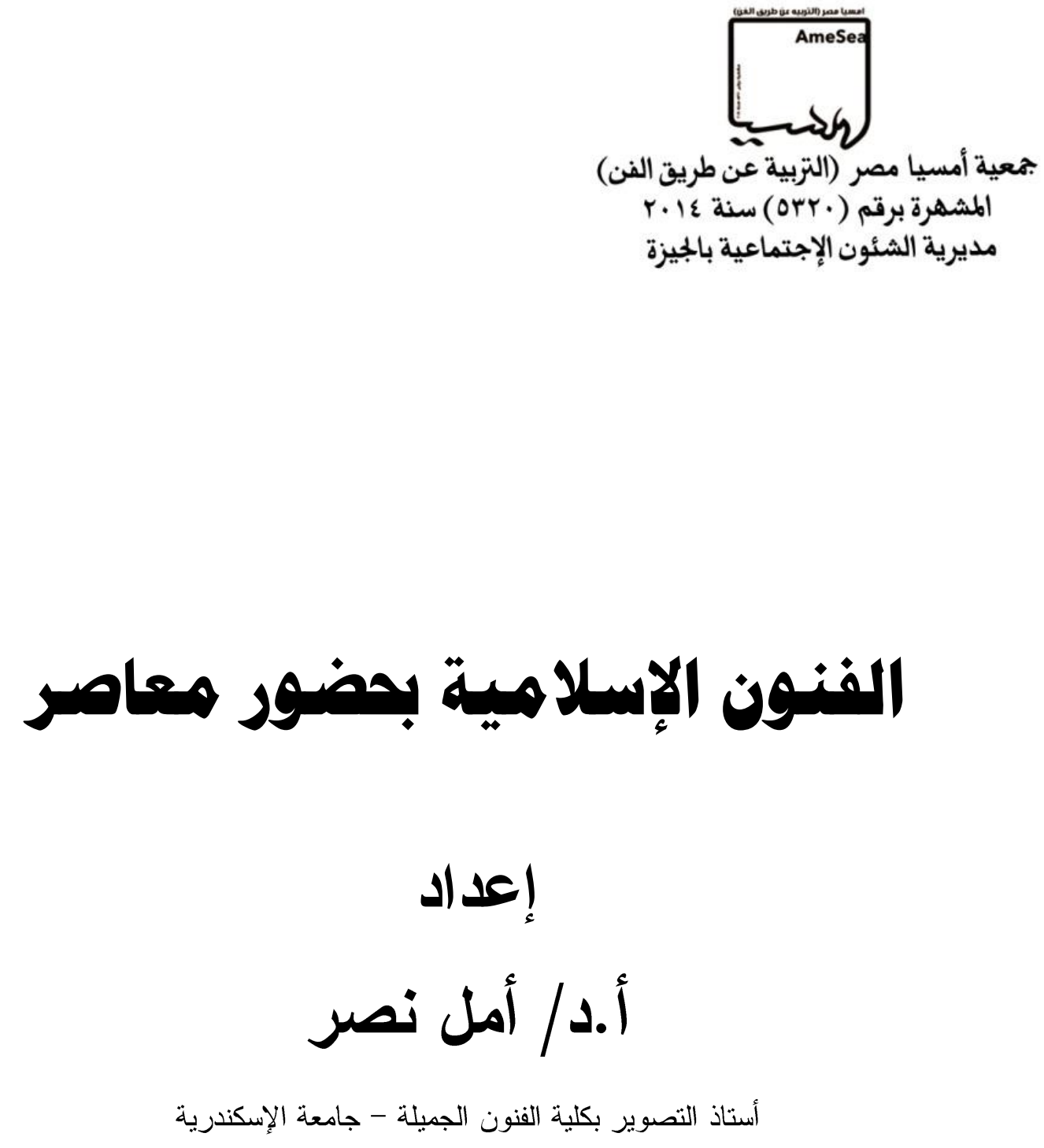

$r+10$

(AmeSea Data Base - ae - Jan. 2015- 0006) 


\section{الفنون الإسلامية بحضور معاصر}

يتمتع العمل الفني الأصيل بحضور دائم ناتج عن قدرته التعبيرية التي لا يمكن حصرها في حدود أفقه التاريخي الأصلي ، فهو يحمل قيمة حاضرة تجعله يحتفظ بقدرثه الدائمة على التواصل معنا و الإضافة لقيمنا الجمالية المعاصرة . فالعمل الفني يدخل في استمرارية تاريخية منصلة حيث يرتبط بعلاقة مع ما سبقه و ما يأتي بعده من أعمال فنية . لذاء فإن إسهام الفنان المعاصر لابد أن يجد له بالضرورة مكاناً داخل هذا النسق المتكامل ، و في الوقت الذي يعتقد فيه هذا الفنان أنه يعبر عن نفسه و أنه متفرد في الخلق و الإبداع و مستقل في النظــر و التفكير فإن إنتاجه في حقيقة الأمر هو نوع من الاستجابة لكل ما

قدمه غيره من الفنانين المبدعين الذين سبقوه ـ (1)

من هنا كان التزاث هو أحد المصادر الهامة لإبداع الفنان ، فالفنان عندما يتتاول ثراثه محاو لاً تفسيرهو إعادة فهمه و تقييمه ، فإن هذه المحاولات اللانهائية تكسب عمله الفني أبعاداً جديدة . وتجعله يبتعد عن تلكك الهوة التي تفصله عن تزاثه ، و هذا ما سماه الفيلسوف الألماني المعاصر " هـ · ج ج · جادامر H.G.GADAMER " بتلاحم الآفاق FUSION OF HORIZONS (ץ). ذلك أن الاختلافات الثقافية بين البشر ، و تباعد الأزمنة ، لا يحول دون ظهور قو اسم مشتركة بينهم خاصة في العالم الداخلي أو الروحاني للإنسان ، و يظهر ذلك عند الفنان في العصر الحديث حيث توجه إلى الفنون البدائية و فنون

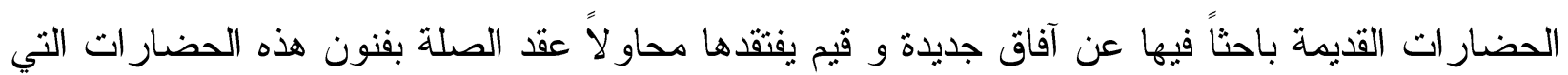
طرحست على المجــال الإبداعي و الجمالي الكـثير مــن القيـــ التي اتفقت مع نوجهات الفـن الحديث.

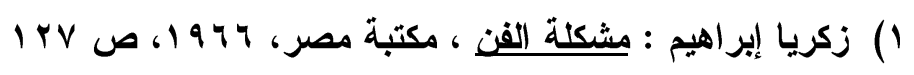

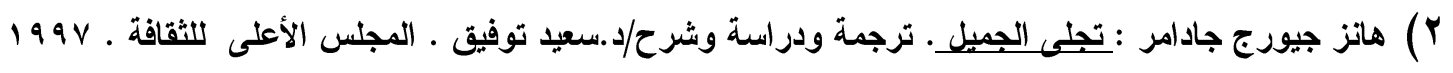


وعندما نتناول هنا الحضور الجديد للفن الإسلامي في إبداعات قطاع من الفنانين المعاصرين فإننا نتتاول مسارين منوازيين الأول يتعلق بمستوى الثكل والثاني يتعلق بمستوى الروح نظراً لوجود

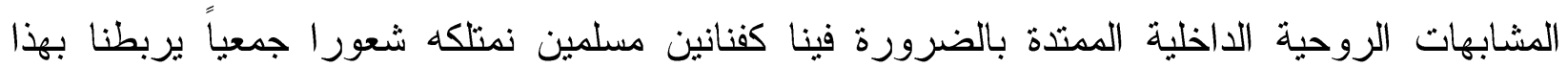
التراث أكثر من غيره وأيضاً أكثر مما يربط به غيرنا من فنانين أوربيين اكتشفوه بصرياً من قبلنا و أعادو ا صباغته فى صور معاصرة فالشكل وحده لا يخلق تواصلاً مع فنون الماضي ، بل يخلقه أيضاً القرابة الداخلية الروحية بين الإنسان وحضارته التي ينتمي إليها ـ

ومن المؤكد أن الفنان المعاصر يتعامل مع تراثه من الفنون الإسلامية بتلك السعة التى تتيح له تتاوله من خلال عدة مستويات وقد سبقنا الأوربيين فى إعادة النظر للفنون الإسلامية وفنون الحضارات الشرقية بشكل عام ليعيدوا اكتثافها و صياغتها فى صور معاصرة من هناستفاد الكثير من رواد الفن الحديث من الفن الإسلامى و ألثقو امعه فى عديد من القيم الجمالية وفى مقدمتها الثورة على المحاكاة، وإخضاع الطبيعة للتقويم التصورى والاستجابة لما يمليه المنطق المجرد للأشكال فى العمل الفنى. ومن الفنانين الذين تأثروا بالفن الإسلامى جوجان وماتيس وبول كلى وإثر وغيرهم . "كذلك مثلت فنون الخط فى

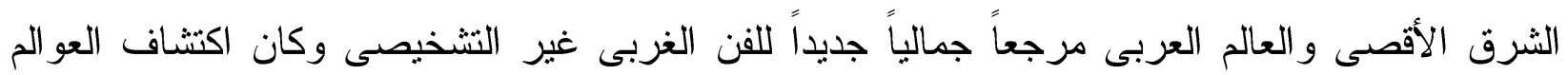
الفلسفية ـ الجمالية و الثقنية لهذه الفنون عاملاً هاماً من عوامل الحداثة الأوربية ، حيث أن أن أحد أهم عناصر الجذب فى الخط العربى ، مثلما فى خطوط شرقية أخرى ، إنما يكمن فى الإمكانيات العديدة التى استطاع هذا الخط أن بستخلصها من امكانات تنضيد للحروف الخطية لايتبع النظام "الجوتتبرجى" ( نسبة جوتتبرج مخترع المطبعة ) ـ ذلك أن التزتيب الحر لعلامات الكتابة ، أى انتزاعها من المنطق الخطى لهن لحروف المطبعة ، قد شكل إحدى الاهتمامات العميقة للفن الغربى ، وقد مهد لهذا الاتجاه المصور بول كلى عندما ابتكر شاعرية كاملة للعلامات الحرة وكتابات الحروف المفردة ، و أكمل هذا التوجه توبيه

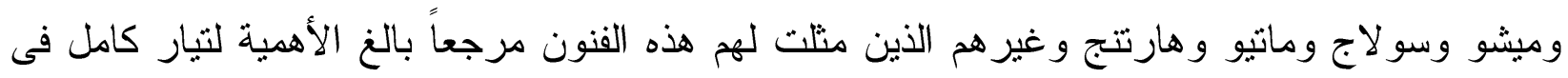

الفن التجريدى " (ب) (ب)

r) طونى مارينى : اسيهامة الجمالبة العربية فى نشأة الفن الغريحى الحبثث ، ترجمة حسن الكاظم مجموعة دراسات

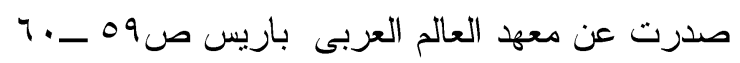


أما بالنسبة لفناني العالم الإسلامي فقد كان الخط العربي هو التجلي الأول لحضور الفن الإسلامي فى

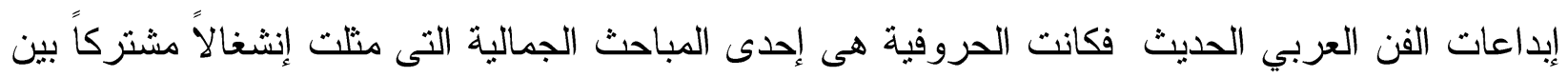
الفنانين العرب بشكل عام ، حيث آمن الكثير من الحروفيين بقدرة الفن الإسلامى ـ ومن تجلياته فن الخط ـ على الخروج ليحمل رسالة من جديد فى إطار البحث عن خصوصية عربية وسط هذا الزخم من الأطروحات الغربية على مستوى الثكل و المضمون خاصة هؤلاء الفنانون الذين درسوا أو أقاموا بالخارج حيث يجعل الاغتراب الفنان أكثر حنيناً لموروثاته خاصة تلك التى تستطيع أن تظل حاضرة من خلا قيمها المتجددة ، كما تمثل بالنسبة له مرفأ أمن ينزح إليه طلباً للخصوصية و الإحساس بأنه يرتكن إلى أصول تاريخ طويل و لايبدأ من الصفر .

من هنا نجد الفنانة العر اقية مديحة عمر تكثف من خلال بيان لها طرحته عام 19 19 عن إيمانها بضرورة أن يتهيأ للفن الإسلامى دفعة تحرره وتثربه من فننا المعاصر وخلال إقامتها فى أمريكا تكتشف الأهمية الجوهرية للحروف العربية ، وكذلك الفنان العر اقى جميل حمودى الذى يقر بأن تجربته الحروفية قد بدأت فى باريس (9 9 (1) كردة فعل ثقافية وقومية على الحضارة الأوربية خوفاً من الضياع فى نراث لايمت لوجوده القومى بصلة ، ويقوم الفنان المصرى أحمد مصطفى أثناء إقامته فى انجلتر ا بتقديم تجربته الحروفية التى ارتاد بها العالم ويحملها النقاد الغربيين بالعديد من مفاهيم الاستبصار الروحى ، ومنلهم يقوم يوسف سيده بتقديم رسالته إلى جامعة " كولمبس أوهايو" الأمريكية فى دكتور اة الفلسفة عام 90 19 وكان "موضوعها الخط العربى فى التصوير التشكيلى الجدارى المعاصر وعلاقته بتزاث الفن العربى" ، وكانت رسالته بحثا شائقاً عن الكتابه العربية وعلاقاتها التشكيلية أثبت فيها بالنظرية والتطبيق أن الكلمة العربية المكتوبة يمكنها القيام بدور هام فى خلق ثقافة تشكيلية جديدة حول العالم العربى عن طريق بناء أثكال فنية تتداخل فيها الحروف الهجائية بين الخطوط والالوان مسايرة للغة العصر السائد مع الاحتفاظ بالروح الشرقية ـ (1) - ب (1)

1) أحمد فؤاد سليم : شاهد عبان على حركة الفن المصرى المعاصر الهيئة المصرية العامة للكتاب ، م ... ، ص V V V 
إلا أنتا نجد الأن طرحاً أكثر سعة بين فنانى العالم الإسلامي لتقصى حضوراً أكثر معاصرة للفن الإسلامي يتضمن صياغات أكثر حرية للخط العربي ويستفيد من الإيقاع الزخرفي الإسلامي ومن أبنية المنمنمات الإسلامية ، ومن خلال هذه الورقة البحثية الموجزة سنتناول تجارب بعض الفنانين ونتتبع الأفاق الجديدة التى ارتحلوا إليها في تناولهم لهذا الرافد الهام في أعمالهم من خلال ثثلاث محاور :

\author{
المحور الأول: الخط العريجي
}

\title{
يوسف سيده
}

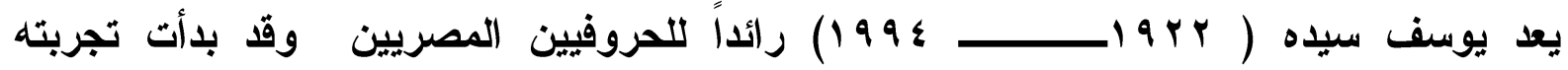
الإبداعية فى منتصف أربعينيات القرن العشرين إلا أنه بدأ تجربته الحروفية التى تألقت حتى عُرف بها فى الستينيات ـ وقد كان مدخله للحروفية متسقاً مع منحاه كفنان ثورى مجدد وأحد الأعضاء البارزين لجماعة الفن المصرى الحديث التى تكونت عام ^؟ 9 1) ورغم ذلك الميل الحر لاى سيده ــ الأى التقى فيه مع الفنانين الغربيين - إلى تفكيك الحرف والتعامل معه كتأثيرات كتابية تثكيلية مجردة فقد اتسمت تجربته الحروفية بحس شرقي عربي خالص ربما يعود مصدره إلى تلك المجموعة اللونية الوهاجة المقسمة فى رقع متجاورة والتى نراها فى أعمال المنمنمات الإسلامية ، والكتابات المغربية المرسمة ، والخيامية الثعبية المصرية التى يعود عهر إزدهارها إلى العصر المملوكى و كساوى

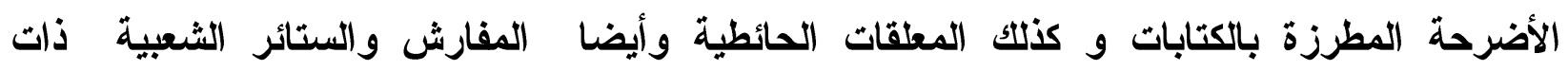
الزخارف الاقيقة المنفذة بطريقة الإضافة ـ والتى يمكن أن نعتبرها جز عاً من المرجعية البصرية ليوسف

كان تناول يوسف سيده للحروف والكتابات تناولاً لايعتمد على التماثل أو فردية الموضوع بل يخلق نوعا من التوتر و التغيير و الخلخلة لكل ما هو ثابت و يعطي نوعا من التكثيف للتكوين فيصبح التكوين فى أعماله ذو نظام متذاخل بدقة يكاد يماثل الفسيفساء ذات الإيقاعات العالية مما يجعل التمثيل في العمل الفني يأتي في المرتبة الثانية في هذا التكوين الملئ بالنبض البصرى المتغير • وهو (AmeSea Data Base - ae - Jan. 2015- 0006) 
بذلك يقدم نوعاً من الخبرة البصرية التى وصفها شاكر عبد الحميد في كتابه " عبقرية الإدراك البصري" بأنها "خبرة دينامية حركية تفاعلية ، وليست خبرة سكونية ثبوتية صامتة أو منعزلة ، فما يدركه الإنسان ليس فقط التظيم الخاص بالأشياء والألوان والأشكال والحركات والأحجام ، لكنه أيضاً هذه التوترات الخاصة الخفية والجلية باتجاهاتها المختلفة يمن النظر إليها باعتبارها قوى نفسية أو طاقات نفسية " لقد حقق سيده التوازن في أعماله الحروفية عن طريق أن تكون العناصر مكملة لبعضها البعض لا متماثلة مع بعضها البعض ، وهو يستخدم في أعماله الوحدات الحروفية منفردة أو مندمجة مع بعضها في شكل ( كولاج COLLAGE) -

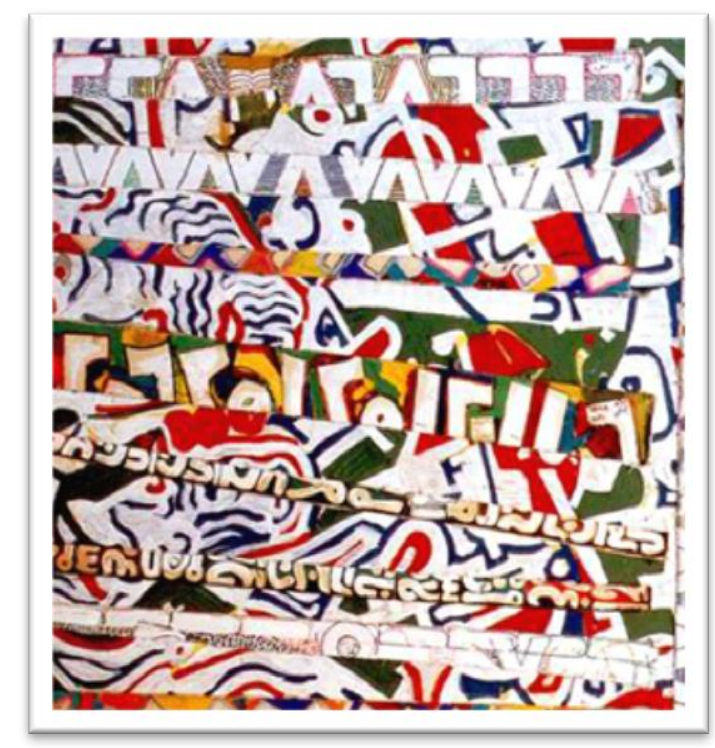

\section{يوسف سيده ، خيامية}

وكثيرا ما يستخدم النقطة أو اللمسات الصغيرة المجزأة باتتظام أو الخطوط المتقطعة كوسيلة لبناء الثكل من خلال إطار تنظيمى متعدد الاتجاهات ، ففى تجاور تلك الأشكال الصغيرة غير المنتظم يتحقق ملمساً ضمنياً يعطى حساً نبضياً يضاهى المطرزات الشرقية الدقيقة ، لقد استخدم سيده الأداء التنقيطى بصورة أكثر عاطفية عندما لم يخضعه للقصدية وللتحليل المعملى الأى قدمه سوراه رائد التنقيطية . ومن تجمع النقاط متناقضة الألوان وتكثيفها وافتراقها نستطيع أن نفسر تلك الإثارة المشعة للشكل فى 


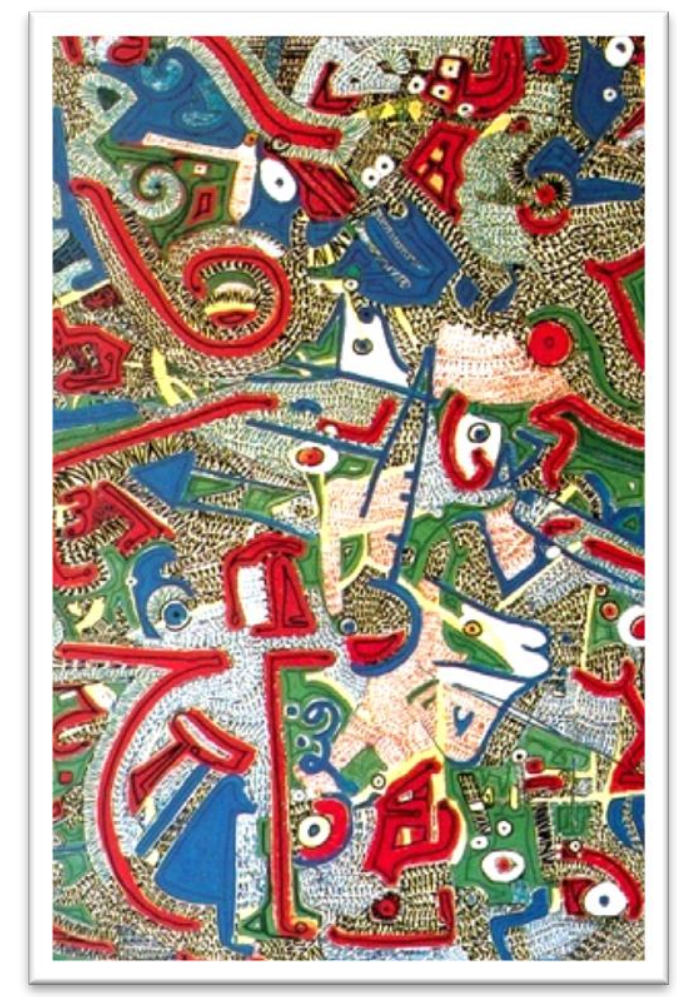

$$
\text { يوسف سيده ، حروف وأرقام }
$$

من هنا فقد استفاد سيده من الخطوط المزدوجة للحروف كما لعب بمقاساتها المتفاوتة وبالأظمة اللونية التى تنتظمها وبالاتجاهات العلزونية الخفية لاوران الحروف والعبارات والنقاط ، لعب بكل ذلك كوسائل لترويض إيقاع لوحاته واتزانها ووحلتها مع حرصه على استخدام الألوان الأساسية مع الأبيض والأسود ليحقق بتجاورها ، ومستويات كثافتها وحدة من نوع بالغ الخصوصية ، 


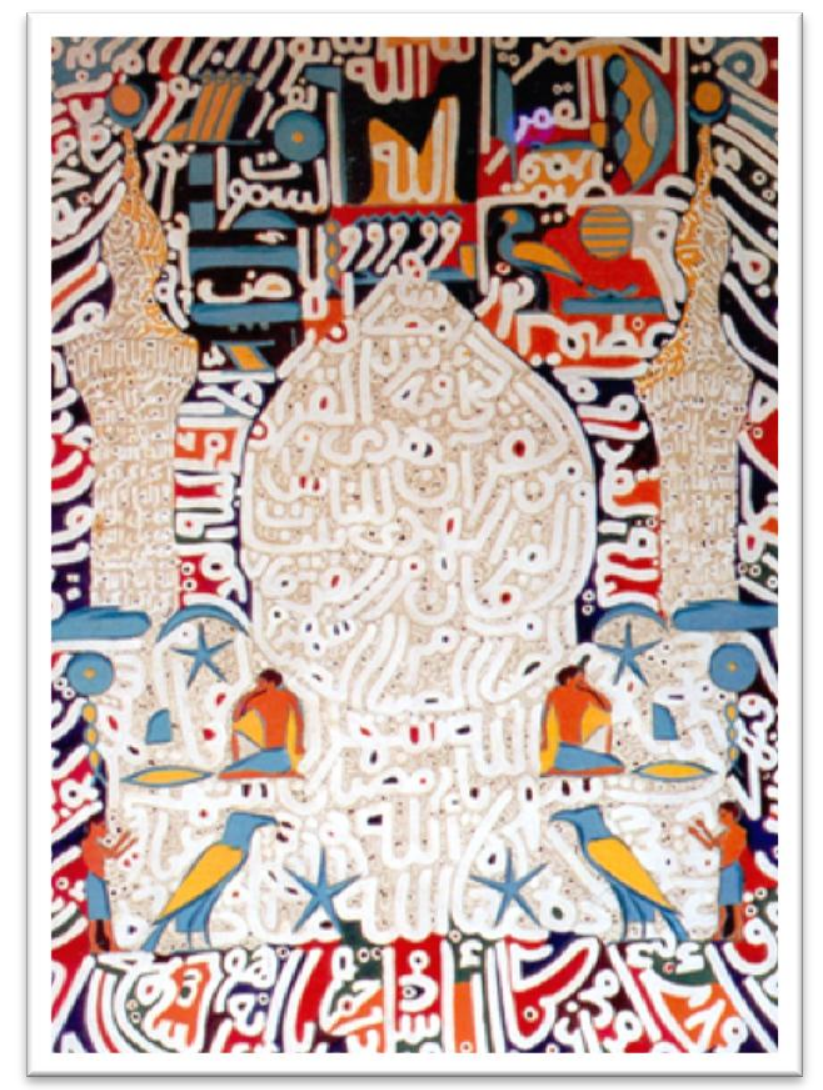

يوسف سيده

لجأ سيده إلى استخدام الأسطح المتوازية أو المقسمة مما يسمح له باستخدام الزخارف الهندسية ، و كان وجود الوحدات مع بعضها البعض و النظام الزخرفي الأي وضعت فيه و الممرات المتتالية في اللوحة ، يجعلها تتداخل جميعها لتعطي مجالاً حيوياً لرويةية العمل .إن تعدد الأثكال المقسمة بعناية ، و الهيئات في علاقتها الحية بالسطح ، و اللون المتوهج كقيمة ثابتة في العمل ، و القيم الاخلية الأخرى للون • كل هذا شارك في تقديم تكوين يميل إلى التجريد . لكن علينا ملاحظة أن " سيده " قد احتذى خطى الحروفيين لكنه لم يتبنى التجريد الخالص . حيث كان يعادل القيم التجريدية و الزخرفية بأشكال من الطبيعة كالنباتات و الشجيرات والعناصر الشعبية بالإضافة للعنصر الإنساني ومن خلال تجربته قدم من خلال للحروفية القائمة على الخط العربي روئة تجاوزت عصره فى المرحلة التى امتدت من الستينيات حتى السبعينيات واختلفت كذلك عن مجايليه الأين لم يتناولوا الحرف العربي بتلك الحرية 


\section{عبد الوهاب عبل المحسن}

يمثل الخط العربي أحد المرافىء التي يلجأ إليها الفنان المصري عبد الوهاب عبد المحسن (1901) من آن إلى آخر متخلاً مر احل تجربته كأحد كبار فناني الحفر في مصر ، وهو يدخل الحروف العربية في نسيج من طبقات لونبة من الصبغات والأحبار والألوان المائية الثفافة التي يلقيها على مسطحه فى هيئة شرائح طولية أو مساحات غير منتظمة حيث يبدأ الفنان بمساحات من الألوان المتتاقضة فيضع بنية أولية للمسطح ثم ما تلبث الكتابات أن تتداخل فى كثافة مكونة ستارة " أر ابيسكية " فوق مساحات اللون الثفيف ، تتتوع حجوم الخطوط فتكبر لتصبح متقدمة في العين أو تصغر لتتر اجع في الخلفية أو ترسم أشكالاً ظلية " سلويت" مبهمة وغير محددة ، وأحياناً ما تقترب الخطوط فتشكل بتكاثقها معا مساحات الظل ، تترسب الحروف متو الية ومتقاطعة متعددة الاتجاهات ومتنوعة النسب فوق نلك البنبة لتنسج طبقة خطية تشكل مسطحاً ثانياً فوق بنيته اللونية الأولى فيتتج عن نلاقيهما الكثير من التأثير ات غير المتوقعة فى مساحات من الضوء والظل التى لم يستخدمها الفنان للتجسيد أو التجسيم بل بسطها على اللوحة فأعطاها شكلاً

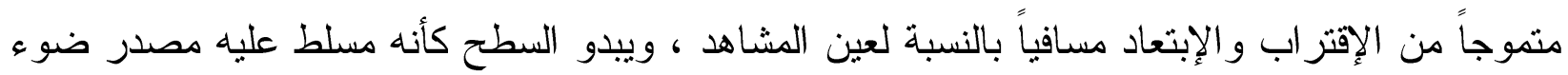
مجهول أضاء بعض جو انب هذا العالم الغرائبي وترك بعضه فى ظلام أو ضباب غامض ، ثم نتتاثر بقع اللون الصغيرة لتسهم فى إضافة إيقاعاً ثالثاً .. هذا الزخم الإيقاعي المتر اتب الثبيه بالتردد الصوفى يحدث تأثيره الخاصة فى العمل فيتحول إلى قطعة من الموسيقى البصرية .

•إن العلاقات البصرية فى الأشكال والأداء النبضى ذو اللمسات والخطوط الدجزأة المتقطعة التى تجتمع. لتعطى الثكل فى النهاية ، يشعرنا تذبذبها وحركتها الداخلية الناجمة عن تتابعها متتالية فى مسارات متحركة ومتغيرة أنها فى حالة تحول مستمر ، ويتغير تأثير ها حسب موقع المشاهد منها فكلما اقتربت من الصورة وجدتها تجريدية تمثل محصلة لمجموعة من الخطوط و اللمسات وبقع اللون الثفاف وكلما ابتعدت عنها كلما رسمت للك مشهاً من الخطوط العربية المتقاطعة ـ فحروفيات عبد الوهاب ذات مظهر تفاعلى

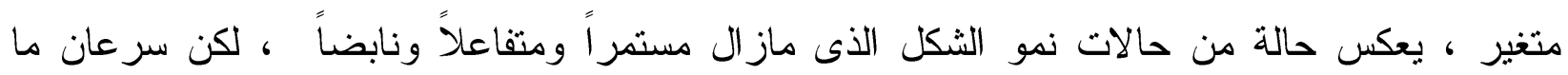
يتحول اهتمامنا من إدرالك قيمة الاستقبال الحسي للأشكال إلى قيمة إدرالك بنية الثكل و النظم التى تحكم علاقاته فتعطيه هذا التماسك . 

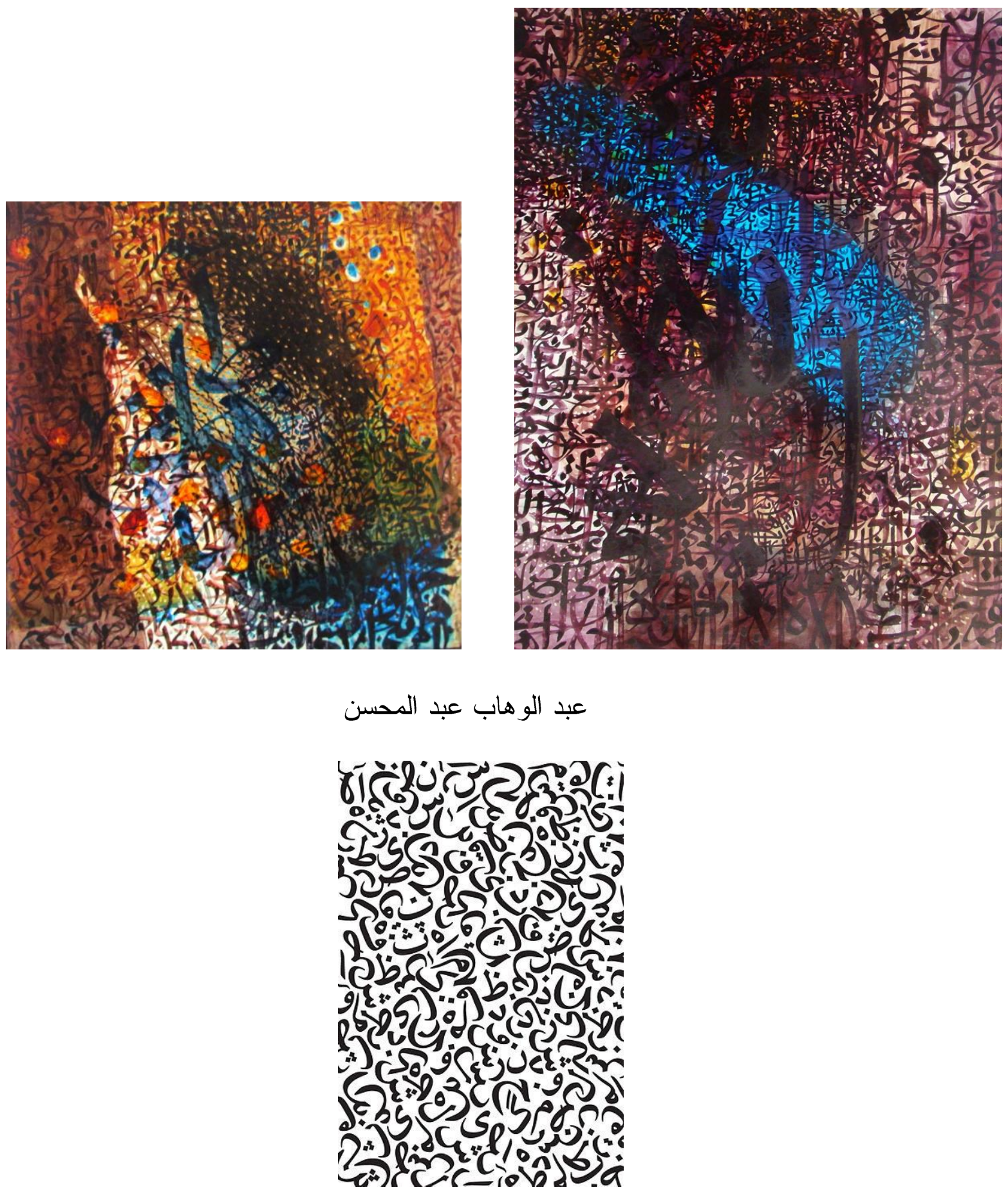

نموذج للخطوط العربية

(AmeSea Data Base - ae - Jan. 2015- 0006) 
ويقدم الفنان حالة من التماهى مع المسطح عبر إيقاع صوفى منتظم فى ترديدات وتكرارات الخطوط

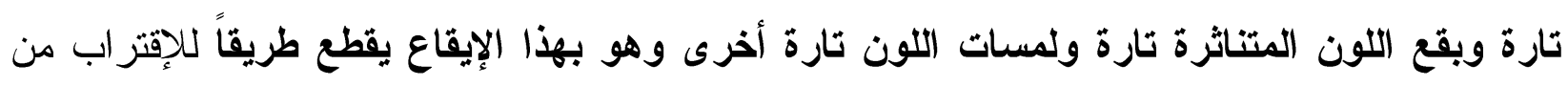
إيقاع الكون الذى يذكرنا بأننا ننتمى إلى كل أكبر وأكثر جلالاً ولا حدود له فيعيد بذلك للخط صفته

يعد الفنان سامح اسماعيل(1974) من الفنانين المصريين الثباب الأين قدموا طرحاً إبداعياً مميزاً فى مجال الخط العربي حيث أعطاه حرية غير مسبوقة فى التناول والأدماج في سياق تجربته التجريدية فقد تعامل مع الحرف كمدرك جمالى حر يتحرك فى بنياته الثكلية منحياً جانباً دوره الوظيفي أو الزخرفي ، فلم يلجأ إلى التكرار المنظم أو التماثل أو التكبير والتصغير وأثباه تلكت الحيل التى فاضت بها أعمال الكثير من الحروفييين كوسيلة للاستثمار اللانهائى للبنية التقليدية للحرف و التعامل معه بشكل ذهنى معملى دون إعطاء مساحة للنمو الحر للصورة وفقاً لقانونها الخاص . ويؤدي الحرف دوره تبعاً لاحتياج اللوحة فهو يعلو دراميا ويشتبك أو يهدأ أو يندمج حسب الإيقاع

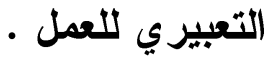

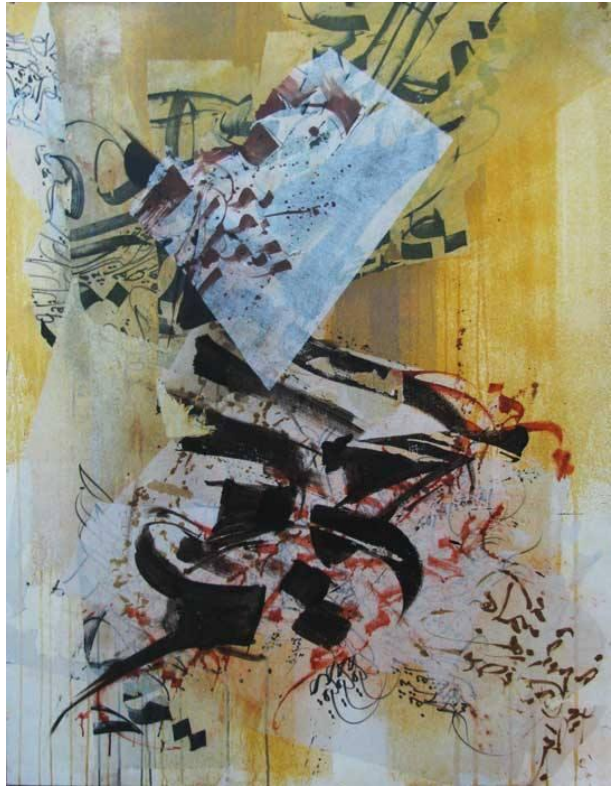

سامح اسماعيل

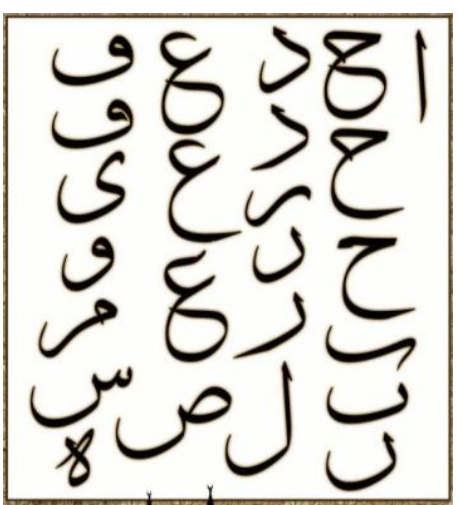

نموذج من الخطوط العربية

(AmeSea Data Base - ae - Jan. 2015- 0006) 
كذلك لم يلجأ سامح لربط تجربته الحروفية بدلالات روحية أو تجربة صوفية ، ذلك الربط الذى

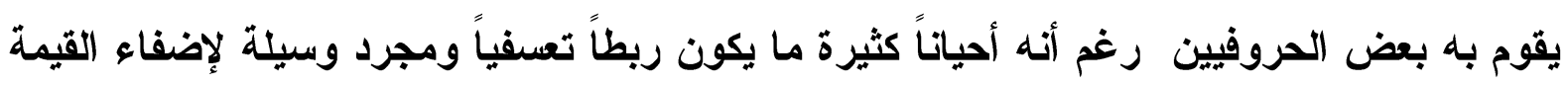
على العمل ، بل لقد نزع عن الحرف صفته المقدة ووصل لحدود مزجه مع الأجساد العارية فى نسيج متراكب فى بعض أعماله ـ فتتاخل بنيات الحرف العربي مع جسد الأثى تغطي أجزاءاً منه مندمجة ميع خطوط خصلات شعرها ومنحنيات جسدها .

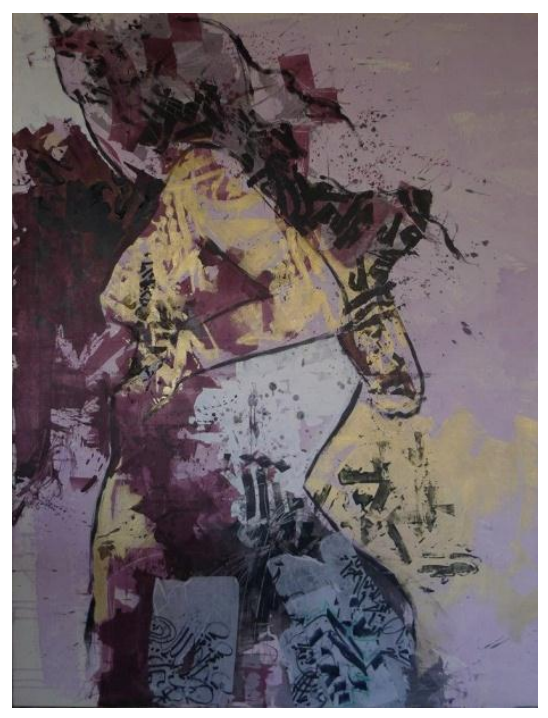

يدمج سامح الجسد مع الحرف العربي مع الخلفية فى اثتباك تسطيحي يفرضه التجريد ، وأحياناً ما يختزل وجود الحرف لينفرط فقط في الخلقية يندمج في ظلها فيتحول لمسطح معتم بينما يتراجع كطيف في بناء الجسد ـ مرة تطمس الحروف الجسد وتثتبك معه وتارة أخرى تبدو كأنها بنية مطمورة في المسطح يطمسها في أجزاء وتركها فى أجزاء أخرى مدمجاً معها بعض الوحدات الزخرفية الإسلامية التى يفكت بنيتها الأساسية ويبقى على أجزاعها مفككة بإيقاع هادى ع مكتفياً بوجودها الإيحائي على البعد ، فهو يثتغل على فكرة طبقات اللون ما بين الثفافية والطمس بأداء حر حيوي لانشعر فيه بالافتعال في الربط بين ايقاع الحرف وإيقاع جد الأثثى بل يدمجهما معا في

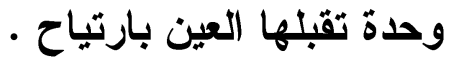

ويزاوج سامح بين منحنيات الجسد الأثثوي ومنحنيات الحرف العربي واتجاهاته وينجح في إحاث هذه التوعمة بسلاسة بين الحرف العربي والجسد الإساني على الرغم من تناقضهما الظاهرى . 


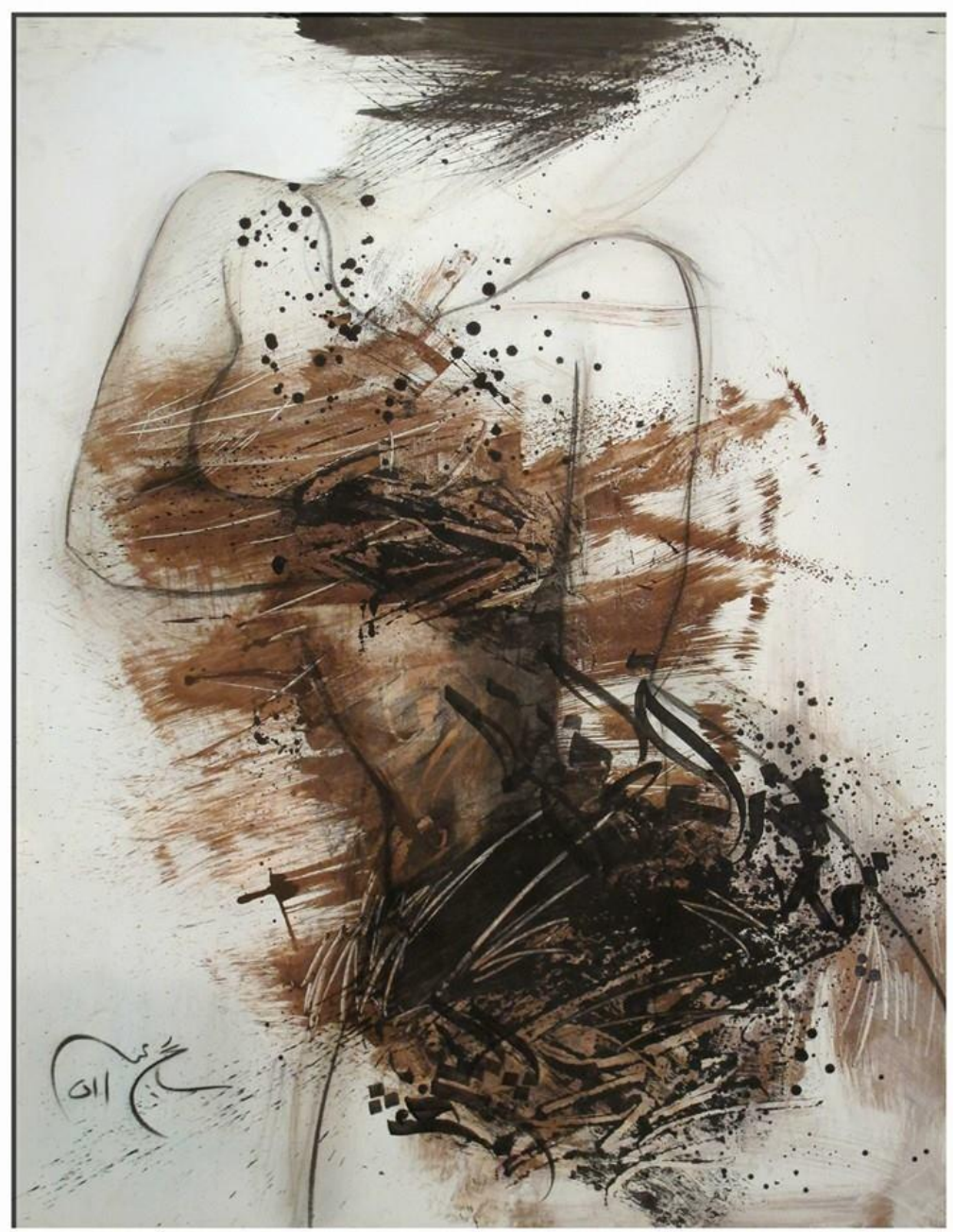

سامح اسماعيل

وفي مجمل أعماله يفكك سامح اسماعيل الخط ليذدمج وسط مساحات المسطح ذات اللمسات السريعة المتتالية في أداء لحظي مندفع لامجال فيه للتردد ، إذ يقتص وهج الاففعال الأولي فيصبح هو المحرك الأول لبنية العمل وهو يمتلك الوعي بطبيعة التوتر الذى تحدثه مختلف المواقف الخاصة بالعلاقات القائمة بين الأثكال والأرضيات فيعتمد على إحداث صراع إدراكى حسى بين الثكل والأرضية؛ حيث من الممكن أن يتحول ما كان يعتبر شكلا إلى أرضية والعكس صحيح. إذ يؤدى هذا التبدل إلى حضور شكل خاص من الإدرالك الحسى وتوتر ذهنى يؤثر فى تلقى العمل الفنى ، والفنان لا 
يقوم باستخدام الأرضية مجرد خلقية يتم رسم خطوط الثكل عليها أو أن يتم شظلها بواسطة أحجام معينة وبدلا من ذلك تعامل "سامح" مع الأرضية بنفس الأسلوب الذى يتعامل به مع الثكل. مما ينتج عنه موقف معين تكتسب فيه كل من الأرضية والثكل خصائص مادية متقاربة وقد أدى ذلك إلى إدر اكهما حسياً بثكل متصل .

ويستوعب المشاهد مضمون هذه العلاقة الملتبسة بين الثكل والأرضية بإعادة قراعتها أكثر من مرة وعلى عدة مستويات ؛ وينشأ التوتر الجمالى بسبب عدم تعودنا على الخصائص التصويرية و التشكيلية العامة للصورة، لذلك يكون من الضرورى أن نقوم بإكتثاف وتطبيق حدودا جديدة لتقييم الجوانب الفنية وفقا لمضمونها العقلى أو العاطفى ، وفى هذا الآتباس بين الثكل والأرضية يكمن بعضاً من سحر الصورة ويتعامل الفنان مع الفراغ على أنه احد عناصر العمل القنى الإيجابية المرنة التى يمكن استخدامها بشكل حر وبالكيفية التى يستخدم بها الثكل الأى يحتل مساحة معينة من الفراغ. وفى الفراغ تنفرط الحروف والنقاط وطرطشات الحبر تخرج وكأنها تغادر أطرها المحدودة ومن بعيد على استحياء نجد حضوراً خافتاً لإيقاعات زخرفية إسلامية بعضها يذكرنا برسوم الخيامية. إن الفنان يقدم صيغة معاصرة لاستخدام الخط العربي بتقطير حروفه إلى أقصى حدود التجريد في تجربة حرة قادرة على التحاور مع الجماليات الجديدة للفن المعاصر • 


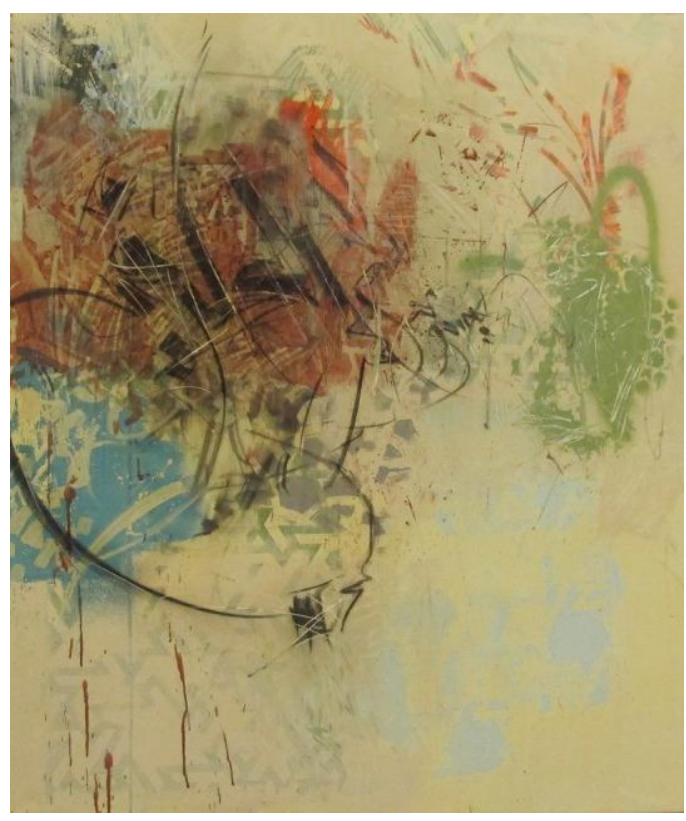

سامح إسماعيل

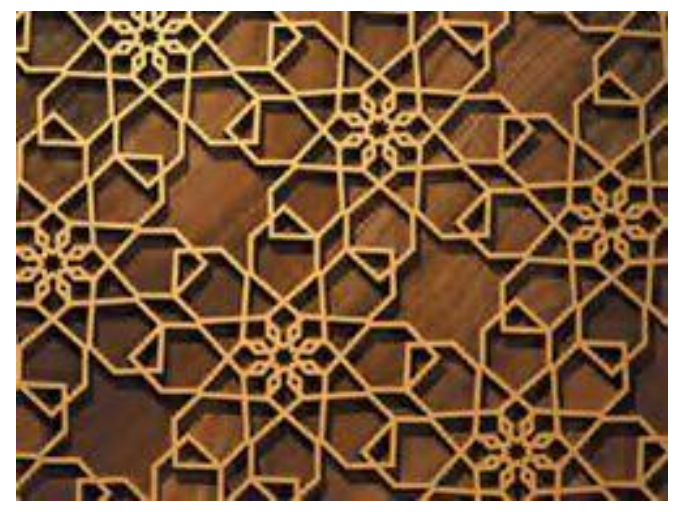

نموذج من الزخارف الإسلامية

(AmeSea Data Base - ae - Jan. 2015- 0006) 


\section{المحور الثاني : الزخارف الإسلامية}

مي رفقي مثلت الزخارف قطاعاً عريضـاً وشريكا في الكثير من أشكال الإبــداع فـى الفـن

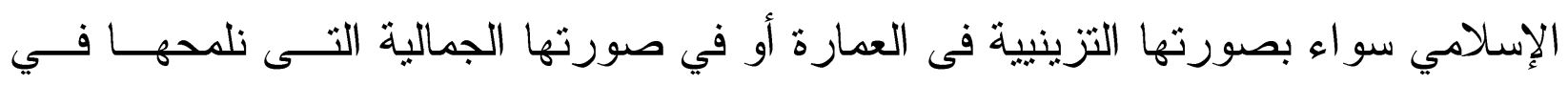
المنمنمات الإسلامية ، فالخالفيات المزخرفة قد مثلت مسـرحاً للحـدث المصــور وللـــص المكتوب في المنمنمة ـ وقد مثلت الزخارف الثرقية الإسلامية منبعاً بصرياً هامــاً لتجربــة المصورة مي رفقي إذ استطاعت أن تستخدمها بنجاح استخداماً تعبيرياً يتتاسب مع تجربتهـــا. التصويرية ـونتذكر هنا مقولة عالم الجمال اتيان سوريو فى كتابه الهام " الجماليــة عبــر العصور " علينا ألا نتمتل الفن الزخرفي الإسلامي الذى تعتبــر الدراســات الجماليــة عنــــ دراسات فى الهنسة أثراً قائماً على مهارة فكرية وعقلية محض ، إنما كأثز يدأب فى البحث عن طرق تبعث على الحلم وتغذيه ، حلم من طينة روحية عالية ، وذلك فى نوع من الفــرار بعيداً عن أثنكال العالم المادي و عالم الجسد ـ كذلك يجب أن نضيف بأن هـــا الفـن قابــلـ لتطويرات واسعة شبيهة جداً بالتطوير الموسيقي.

وفي هذا السباق نطرح تجربة مي رفقي لنلاحظ أن الزخارف الإسلامية تثغل مساحات

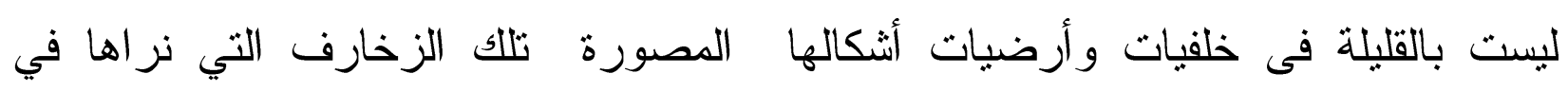

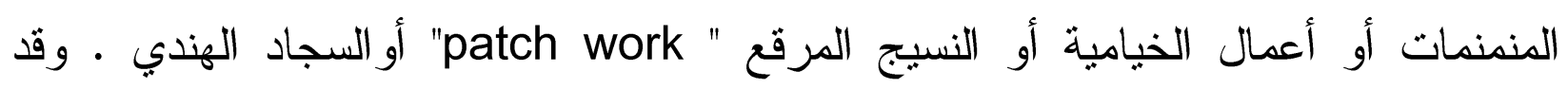
قدمت الفنانة تصور ا خاصا للسطح من خلال التكوينات المتعددة لهيئات هامة في علاقة مع أجزاء الخلفية تسمح بظهور منمنمات مندرجة داخل المساحة استخدمت فيها وحداته 
الزخرفية المنميزة . و تحول السطح التصويري لنسيج مليئ بالحركة و الإيقاع الذي تنكثف فيه العناصر مكونة هذا الملدح الثرفي الخاص المعتمد على الوحدات الزخرفية التي حولتها الفنانة من مجرد حلية أو زينة إلى أداة للتعبير وفراغ للحلم والبعد عن الحالة الأرضية التجسيدية لتضع شخوصها في مجال بصري موح ومنفتح ويميل لحالة من التجريد التعبيري 


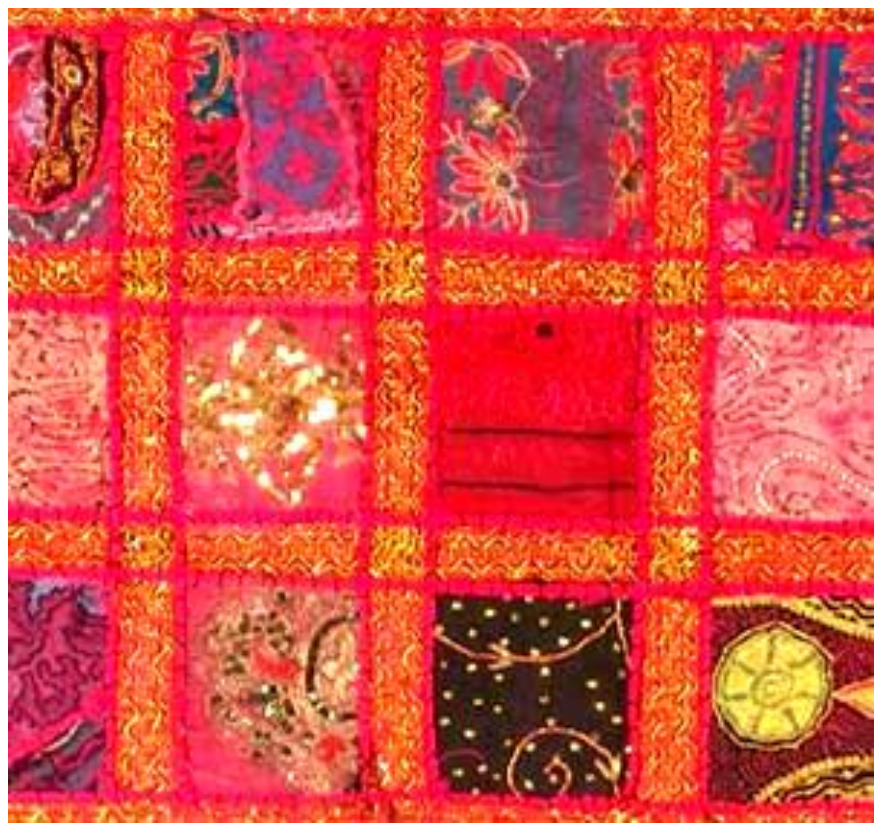

عمل من فن " |patch work" رقع النسيج"لهندي

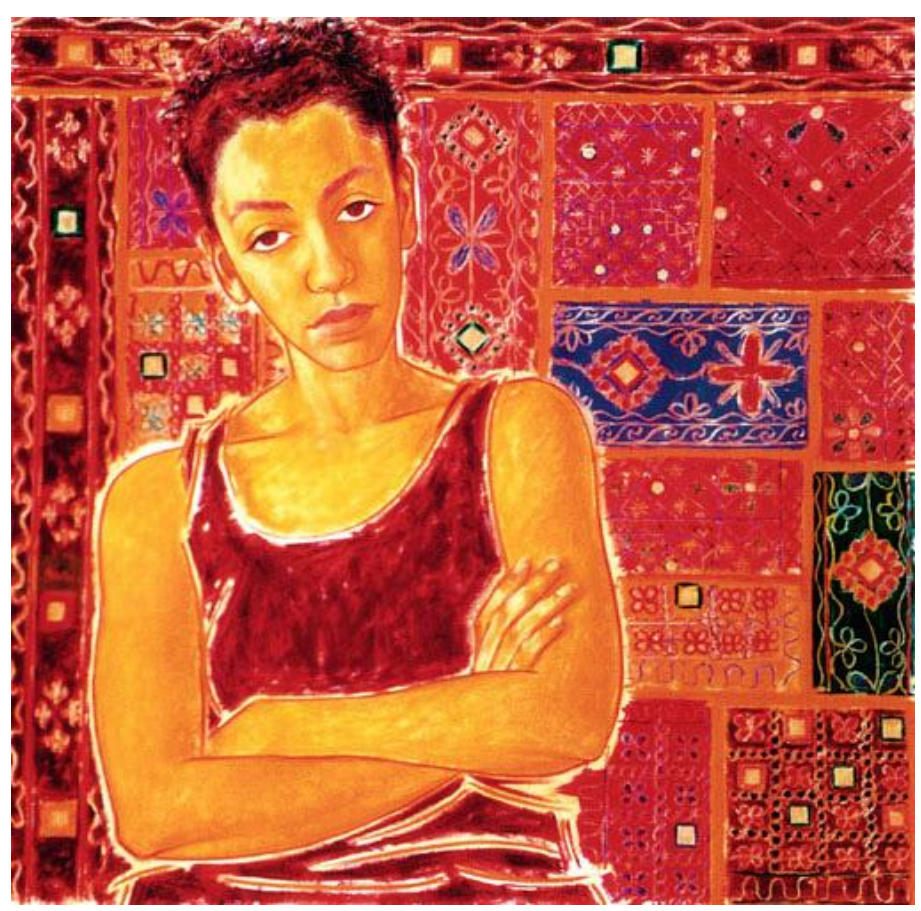

عمل للفنانة مي رفقي

(AmeSea Data Base - ae - Jan. 2015- 0006) 
وقد جمت مي في تكويناتها بين ( وحدة الثيء أو الثكل ) ، والثكل المفتوح و ذلك عن طريق تصوير شكل رئيسي في المساحة غالباً ما يكون العنصر الإساني - و بين قطاعات أو ممرات طويلة أوعرضية تمتد بموازاتها تحللها لمجموعة من الزخارف و الأشكال ليغيب حجم الجسم و يتسامى وسط شبكة من المنحنيات الزخرفية التي تبدو كما لو كانت خلية تزدحم بالأشكال النابضة .

بهذا التناول للعنصر الإسانى تعتمد مي رفقي فكرة " تغريب الجسد " أي عدم الاهتمام بالجسد كعنصر مادي له حجم ووجود منفرد في العمل الفني وهى فكرة ذات أصول شرقية قديمة نراها فى اللفائف الصينية والمطبوعات اليابانية كما نراها فى المنمنمات الإسلامية وهى ترى أن الوجود العقيقي لأي شكل يكمن في بساطته مع احتفاظه في ذات الوقت بأنقى خصائصه وسماته ، وفي توحده مع كل الموجودات الأخرى وربما تلك الخاصية الجمالية كانت هي السبب في عدم إعطاء الجسم الإساني وضعاً مميزاً في العمل الفني الثرقى بل صور كجزء من نسيج داخل العمل لايتمتع بتبجيل خاص ؛ لأ كان يُصَور مسطحاً و محلاً لمجموعة من الخطوط أو الزخارف و بنفس درجة الاهتمام

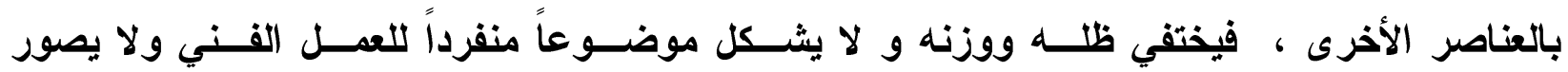
مستقلاً عن خلفيته كما نشاهد فى تصوير " البورتريه " فى الفنون الغربية .

وتمنح الزخارف الثرقية والإسلامية لتصاوير مي رفقي تلك الصيغة التعبيرية المبهجة إذا جاز لنا هذا التعبير حيث تغمر نماذجها الإنسانية بها وتنسجها معها بشكل تصنع معه عالمها الخاص ، قد تحقق ذلك من خلال خلفياتها التى تتناثر فيها الوحدات الزخرفية أو من خلال قطاعات مزخرفة تقيم بها بناء الصورة تصميمياً . 


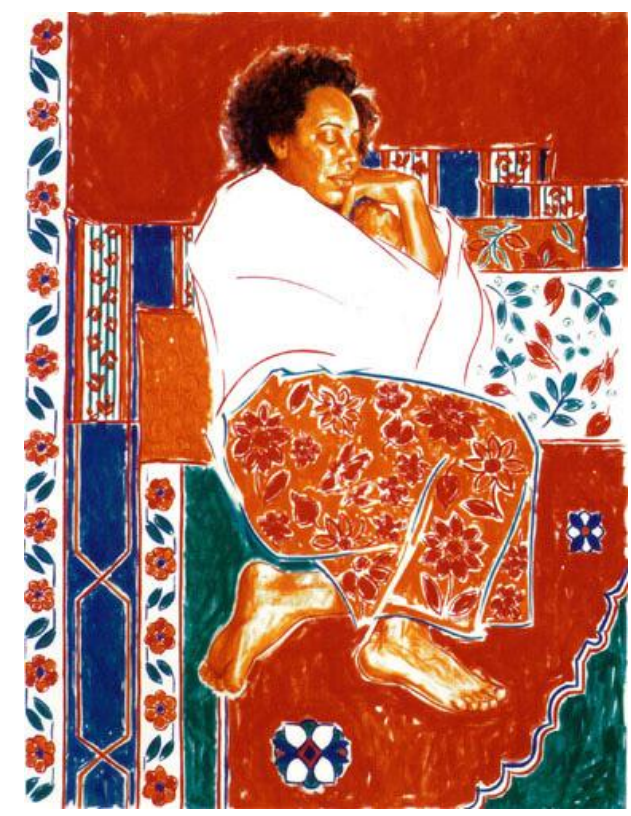

عمل للفنانة مي رفقي

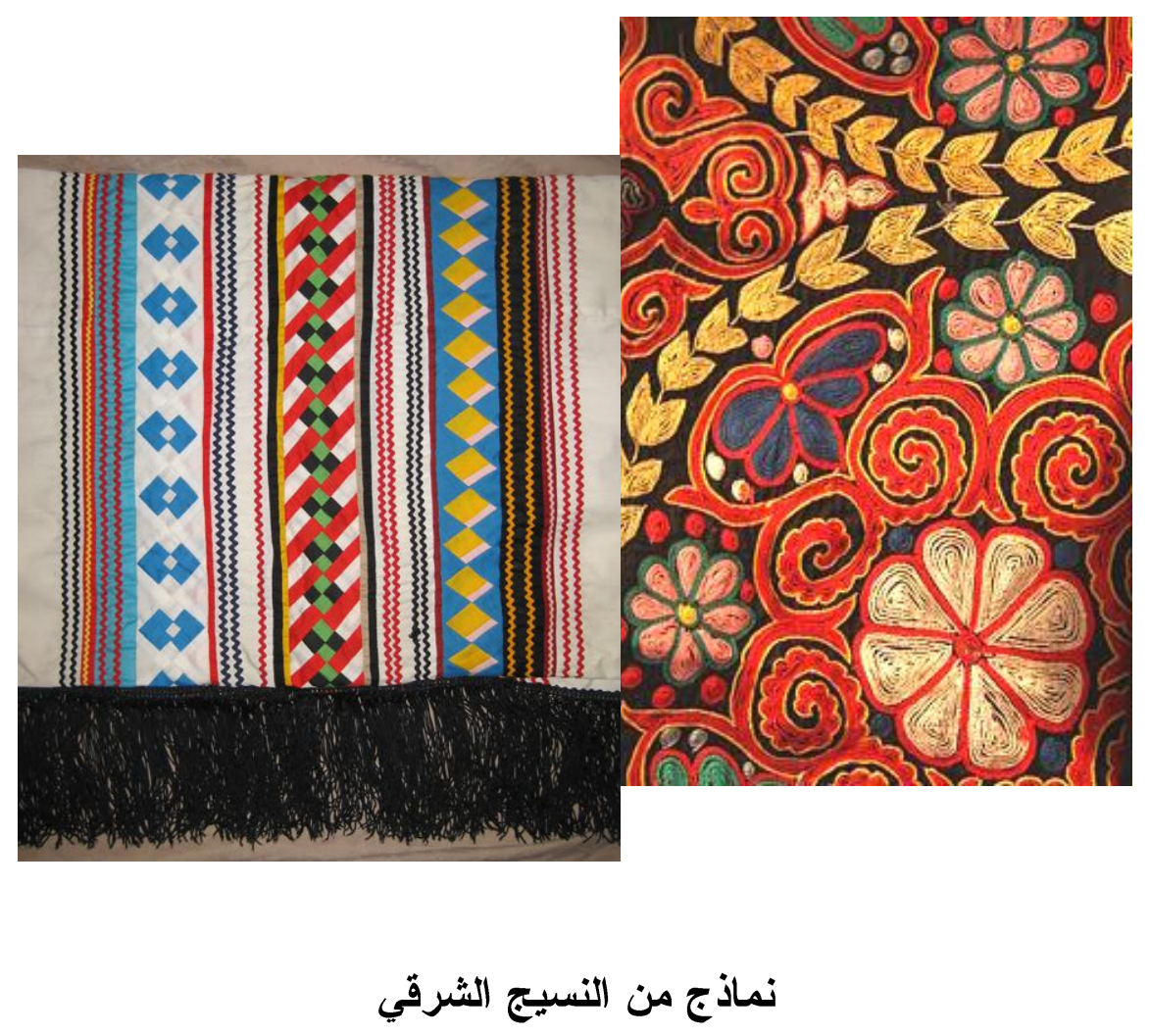

(AmeSea Data Base - ae - Jan. 2015- 0006) 
وقد تبسط مي الزخارف كسدائل في خلفيات العمل أو ملابس شخوصها أو كأردية يلتفون بها وقث تثتبك تلك الزخارف مع الخلفيات وتتفكك أكثر لتضاهي بصرياً نفس تأثير لمسة اللون ونفس وقع إيقاعها الاففعالي التعبيري السريع الأي تبني به اللوحة المصورة

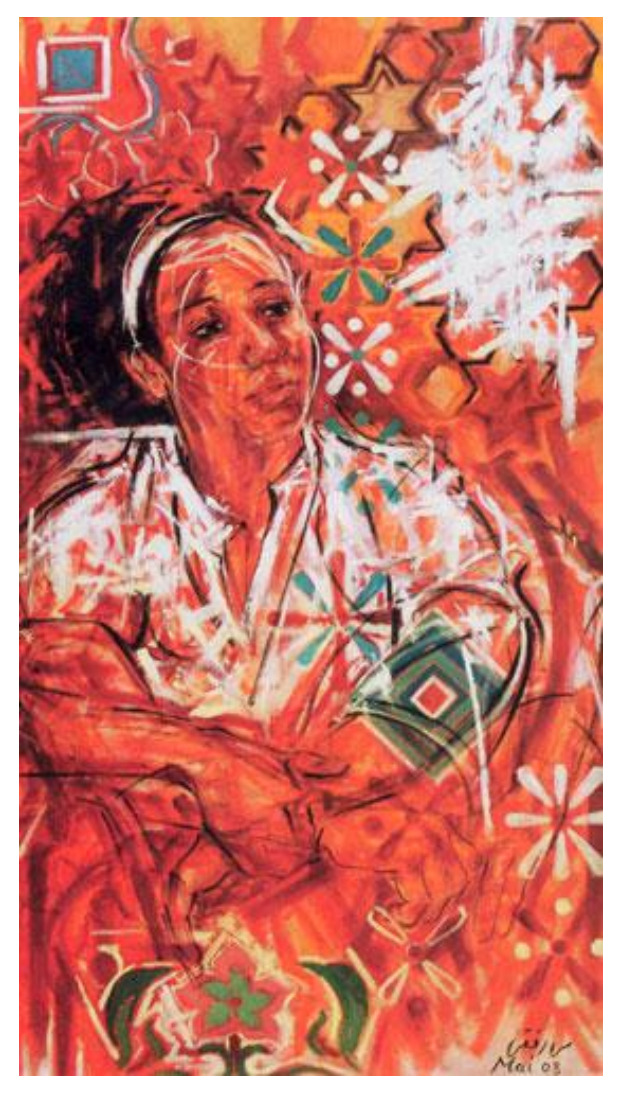

$$
\text { عمل للفنانة مي رفقي }
$$

وفى أحيان أخرى تستخدم الفنانة الزها خارف في مسطحات تتناوب مع مسطحات لونية فارغة فتتعادل معها أو مسطحات متجاورة لتشكل قطعة من الفسيفساء أو تضع بشكل ظاهر وحدة كاملة من وحدات الخيامية الشعبية بينما تعيد نوزيع نفس الوحدة بشكل أكثر تلخيصاً وخفوتاً فى فضاء العمل ، أو كتضع مقطع زخرفي مستقل في خلفية العمل يصنع حواراً بصريا مع الشخصية المصورة 


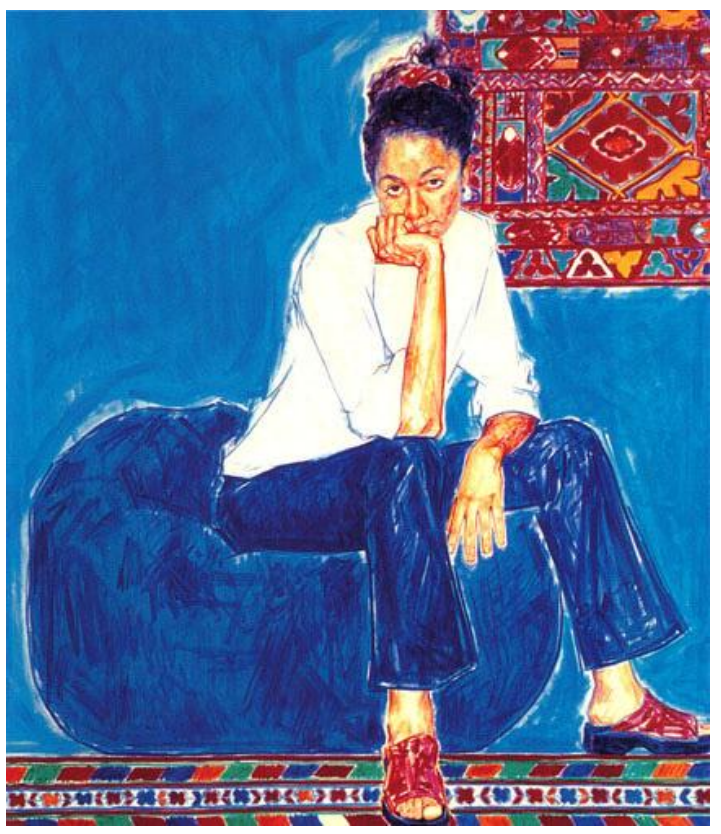

عمل للفنانة مي رفقي

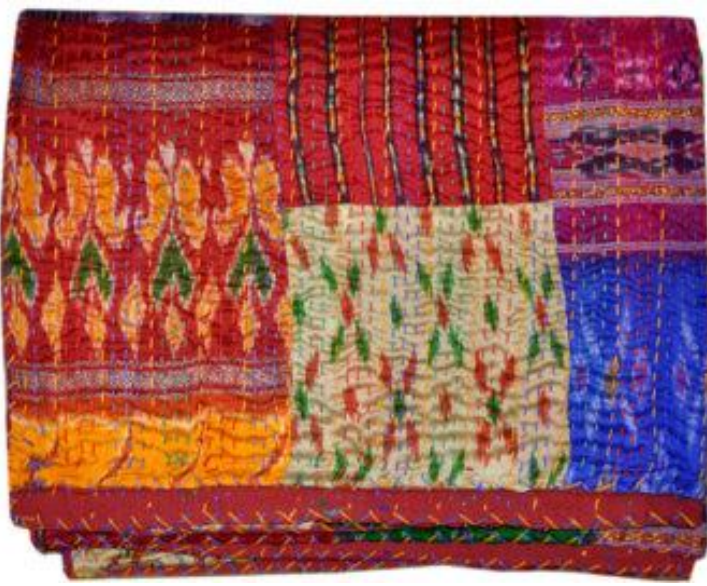

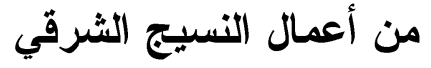


و هكذا من خلال الزخارف الإسلامية نظلق مي نوعامن النوتز و التغيير و الخلخلة لكل ما هو

ثابت و تعطي نوعا من التكثيف للتكوين فيصبح التكوين ذو نظام متداخل بدقة يكاد يماتل الفسيفساء ذات

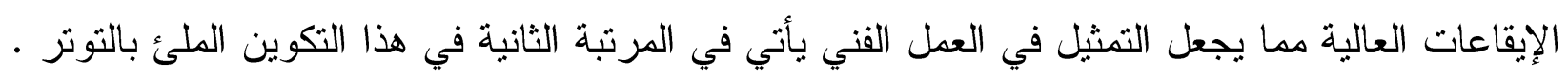

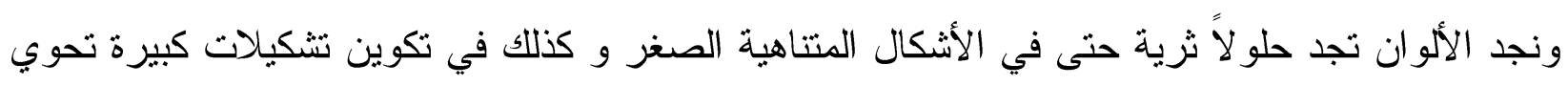

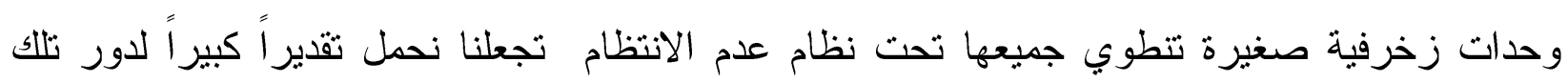

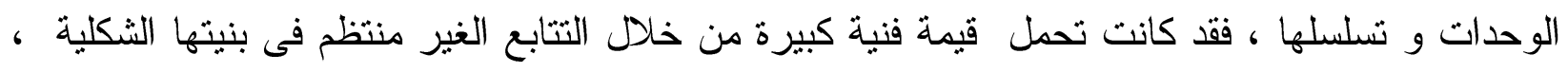

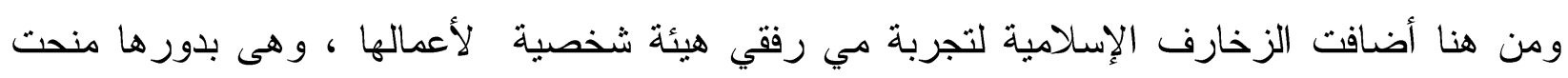

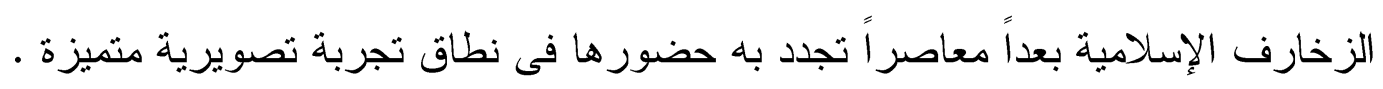

نادية وهدان

تقدم لنا الفنانة نادية وهدان (19VVV) تجربة جليدة في تصوير الوجوه عبر استخدامها الزخارف

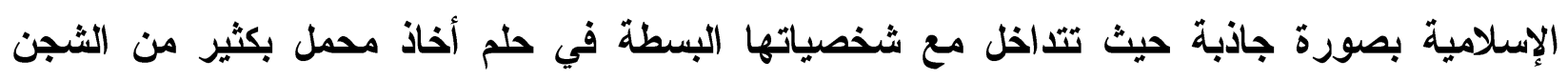

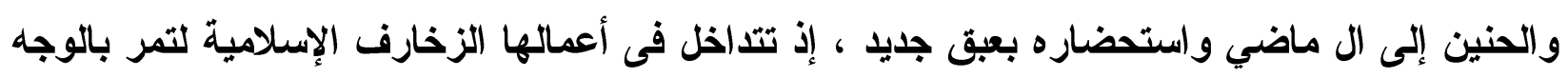

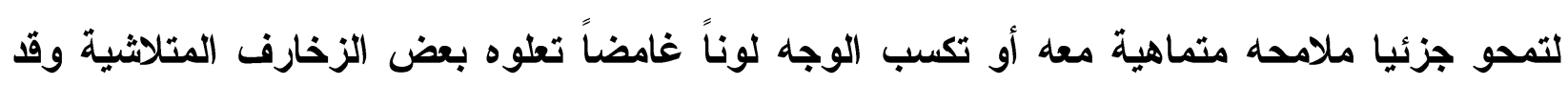

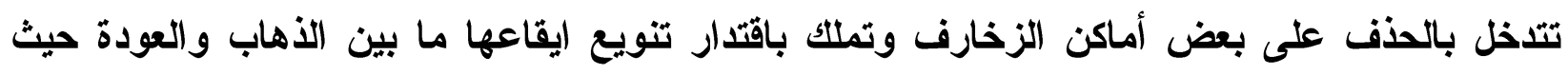

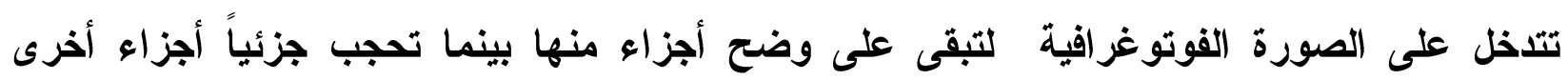

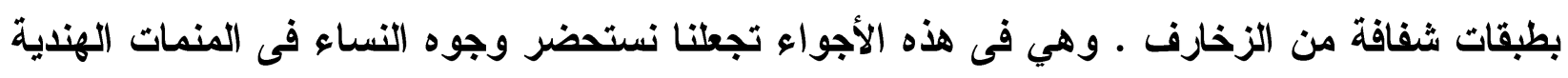

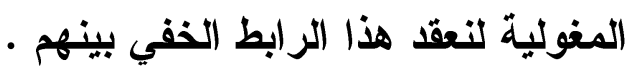



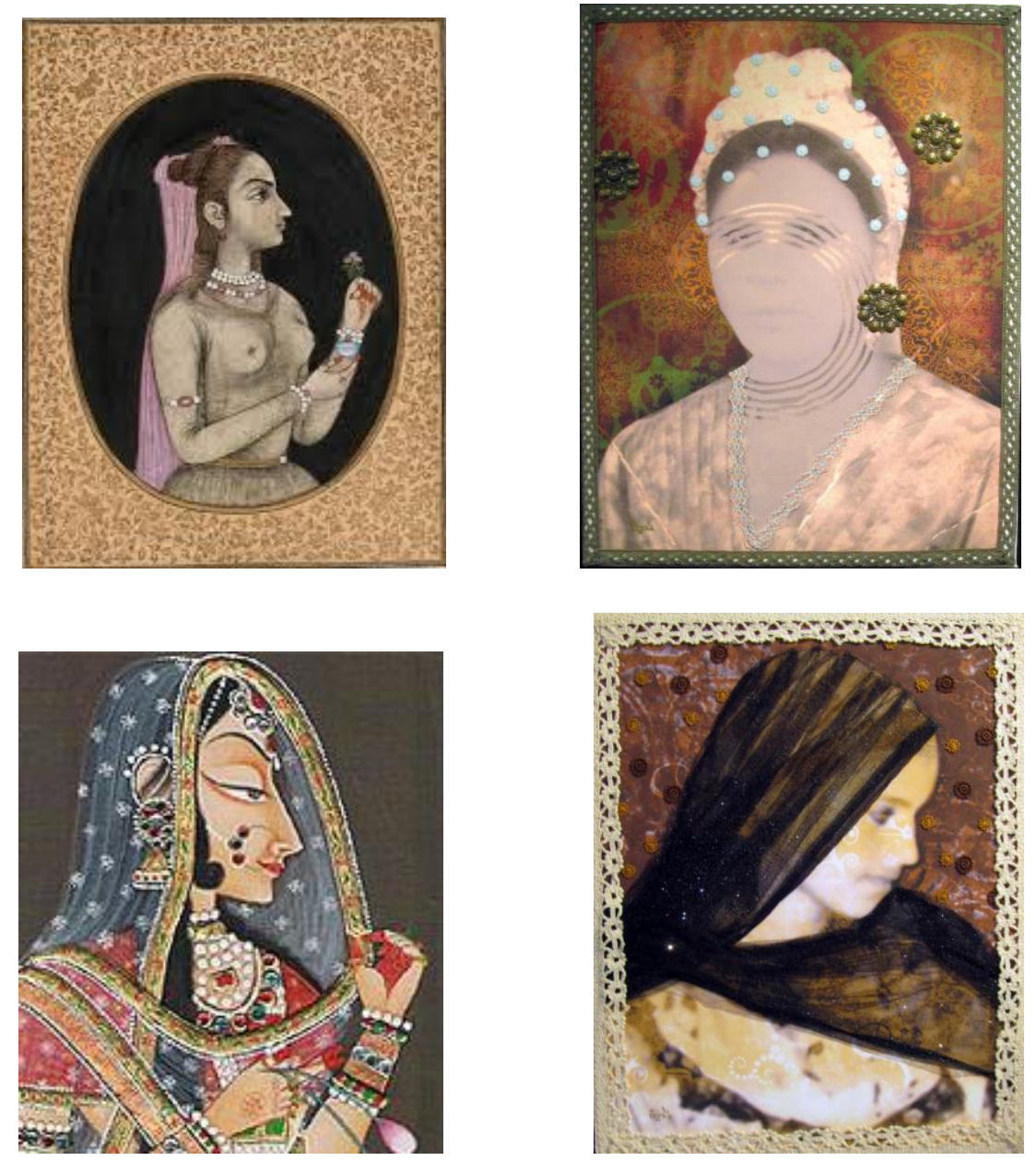

نماذج من منمنمات هندية

نادية و هدان

وأحياناً تلف الفنانة الوجه بيشمك مزخرف يزهو بورده ولأئه وأحياناً أخرى يغمر الوجه مساحة من الأبيض نوراني الحضور وهي تستخدم الضوء بحساسية حالمة ، يغيب ويظهر ، يخفت ويتألث حسبما تحدد له من مواضع للغياب والحضور • إنها تستخدم الصورة الفوتوغرافية القديمة التح تنفذ إلى وجداتنا الأي يحن إلى الماضي بأسى أو شجن أو محبة لنتدمج معها فى هذا الحلم الفردوسي الممتا 
وتختار الفنانة أجزاء من الزخارف لتنفذها بقطع من الانتيل وتلصق عليها الورود واللألىء والحلي. المعدنية فتمزج الخيال بالواقع والمسطح بالمجسم بصورة مثيرة نحب أن ننظر إليها . تضع نادية الهالات الزخرفية حول رؤوس قديسيها الجدد من المصريين الكادحين فلاحات مصر الطيبات تصبحن ملكات في أعمال نادية ، نتذكرمعهن حوريات الهند وبنات جوبي وصور العاثقات في المنمنمات الفارسية ولكل وجه حالة : وجه فِرح ،وجه حزين ، وجه كادح ، وجه مطموس • إنها وجوه مصرية تدخل عليها الفنانة رقائق شفافة من ستائر زخرفية تتحم في حضور طبقاتها الخطية واللونية فتحذف أجزاء وتبقي على أجزاء وتغيب فى اللون البهيج أجزاء أخرى ، وقد تنتخب بعضها فتظهره وتنحي البعض وتغيبه في الخلفية مما يكسب الزخارف التى تعودناها مسطحة أبعاد مسافية ، كما تكسر انتظامها الزخرفي فتلخل في سياق تعبيري ورمزي موح حيث تحدث المفارقة بين الواقع والتاريخ ،

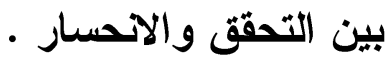

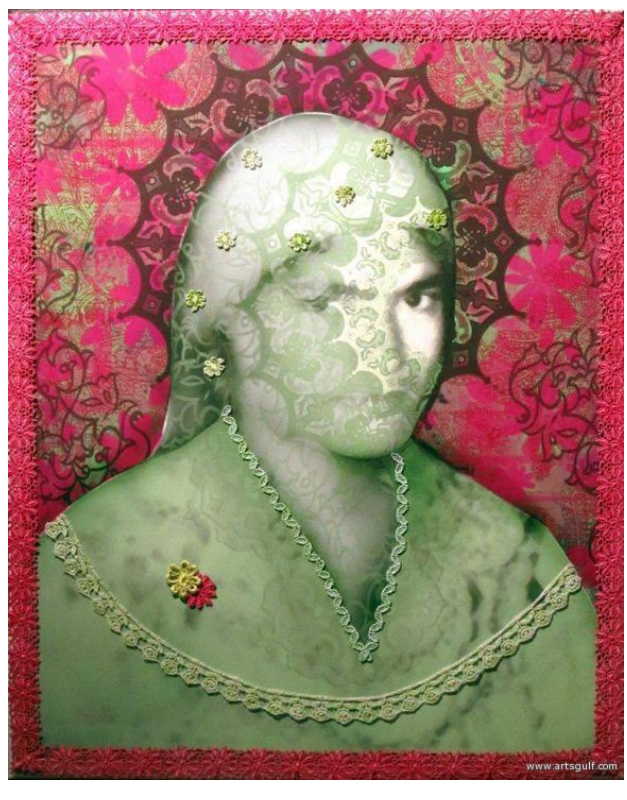

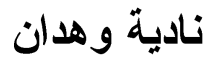



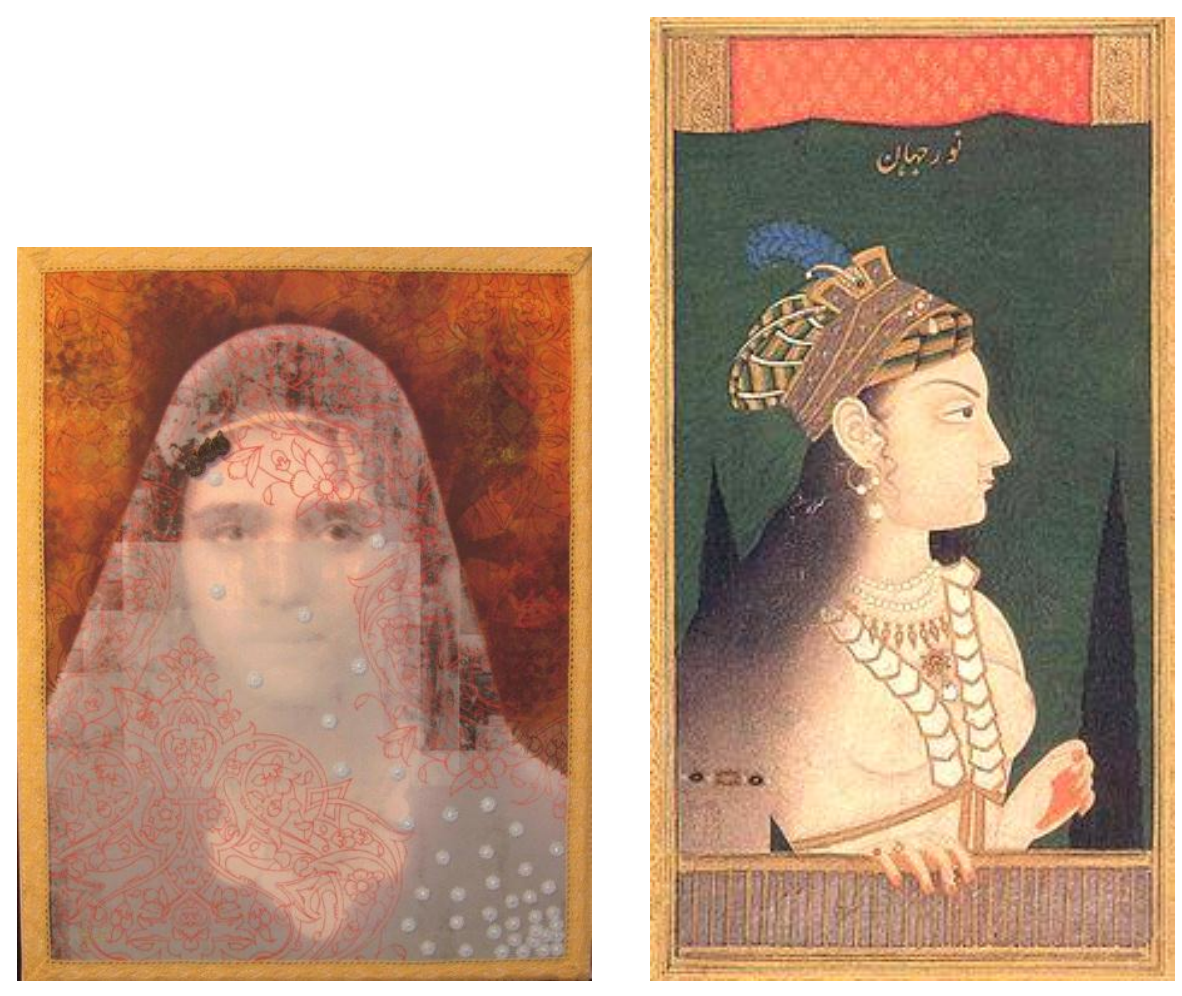

نادية وهدان

نموذج لمنمنمة هندية

إن غياب هذه الثخصيات في تلكك الأجواء يجعلها تبدو وكأنها في حلم متصل خاصة عندما تذهب بنا الفنانة بعيدا عن الأرض فيأخذ الوجه لوناً أخضر إميرالدياً أو أزرق فيروزي يذكرنا بوجوه الإله الهندي

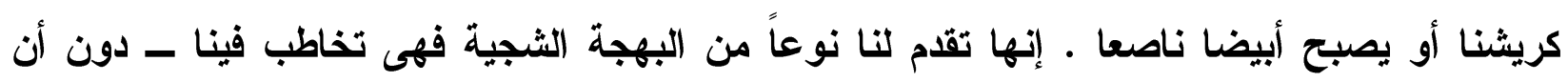
نشعر- ذكرياتنا حول تلك الوجوه الحبيبة التى تمثل النموذج الأصيل للإنسان المصري البسيط والذى لابد أن لكل منا بعض المحبين الأين يشبهون هذا النموذج : جداتنا ،عماتنا ، خالاتنا ، أقاربنا ، جيرانتا ، وحتى بطلات رواياتنا وقصصنا الثعبية وحواديتنا ـ ل

هن هنا أضفت نادية وهدان على الزخارف الإسلامية بعاً إنسانياً عاطفياً يلعب على الوتر المشدود في قلب كل إنسان ، وتر الأحباب الذين تفتقدم أعينتا ـ مل في 


$$
\text { نادية وهدان }
$$

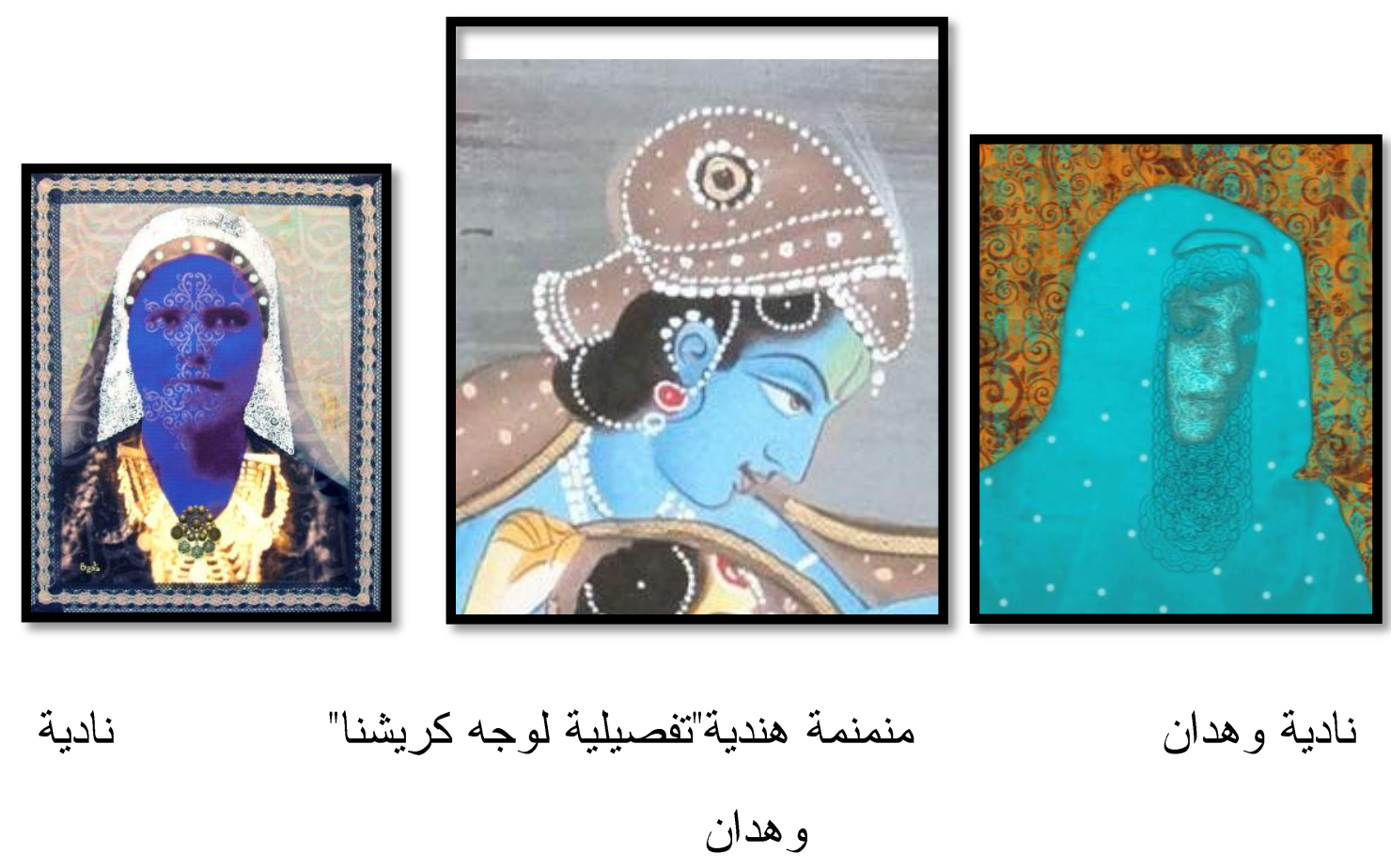




\section{المحور الثالث : المنمنمات الإسلامبة}

المنمنمة هى ذلك المعبر الذى افتتحه الفنان المسلم لكى يبدع من خلاله عوالم غرائية فيحة ضمنها بكل صور الحياة فى أوج امتلائها وبهجتها ، وهى الشكل الفنى الوحيد فى التصوير الإسلامى الذى اتسع ليشمل مظاهر الحياة الدنيا بحكايات عشاقها ودحبيها وحروب فرسانها و أدبيات فنانيها واختر اعات علمائها وأدوية أطبائها و أعمال بنائيها وحتى بصور شياطينها وحكاياتها الخرافية ، كما اتسع أيضاً ليحلم بمظاهر الحياة الآخرة التى يأملها ويتمناها من جنات ونخيل و أعناب وحدائق غناء.

تضعنا المصورة الإسلامية ( المنمنمة ) على منل رحب فى كيف تتسع الصورة وتتكاثف فيها الرؤى حتى تتجدل فيها خيالات غير محدودة ، وبدلاً من أن تغلق باب الخيال بأن تضع المشاهد أمام تمثيل و احد للكلمة المكتوبة فإنها تقتح هذا الباب على دصر عبه حتى بتشع لكل تصور • ووسط كل الفنون الإسلامية التى تعادلت فيها القيمة الوظيفية والقيمة الجمالية كانت المصورة هى الشكل الوحيد الذى أنطلق فيه الجمال ليبلغ سعته متجاوزاً حدود الو اقع بخيولها الزرقاء و أشجار ها الوردية وسماو اتها التى تعج بالمخلوقات الخر افية وتصويرها الخاص للمكان الذى يُحلق داخله المشاهد ليرى كل تفصيلية فى المصورة من زاويتها الأكثر تعبيراً وجمالاً غير حافل بحدود الرؤية البشرية ولا بصندوق المنظور الهندسى الغربى •

وقد لقيت المنمنمة الإسلامية حضوراً جديداً فى الفن المعاصر من خلال تجارب ضمنتها العديد من قضايا و اقعنا المعاش ودن هذه التجارب ما سنعرضه تبعاً : 


\section{Shahzia Sikander شازيا اسكندر}

ولات الفنانة شازيا اسكندر عام 979 1، في لاهور،- باكستان ، درست المنمنمات الهندية والفارسية دراسة تقليدية فى الكلية الوطنية بلاهور ثم انتقلت إلى الولايات الأمريكية المتحدة لاستكمال دراستها

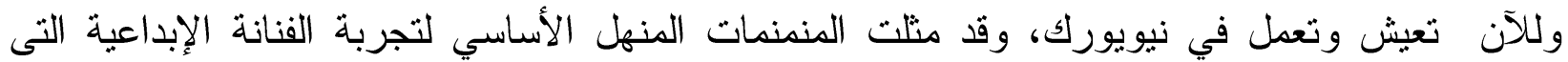
تتو عت ما بين الرسم و التصوير و التجهيز في الفراغ و والعروض وضك والفيديو .

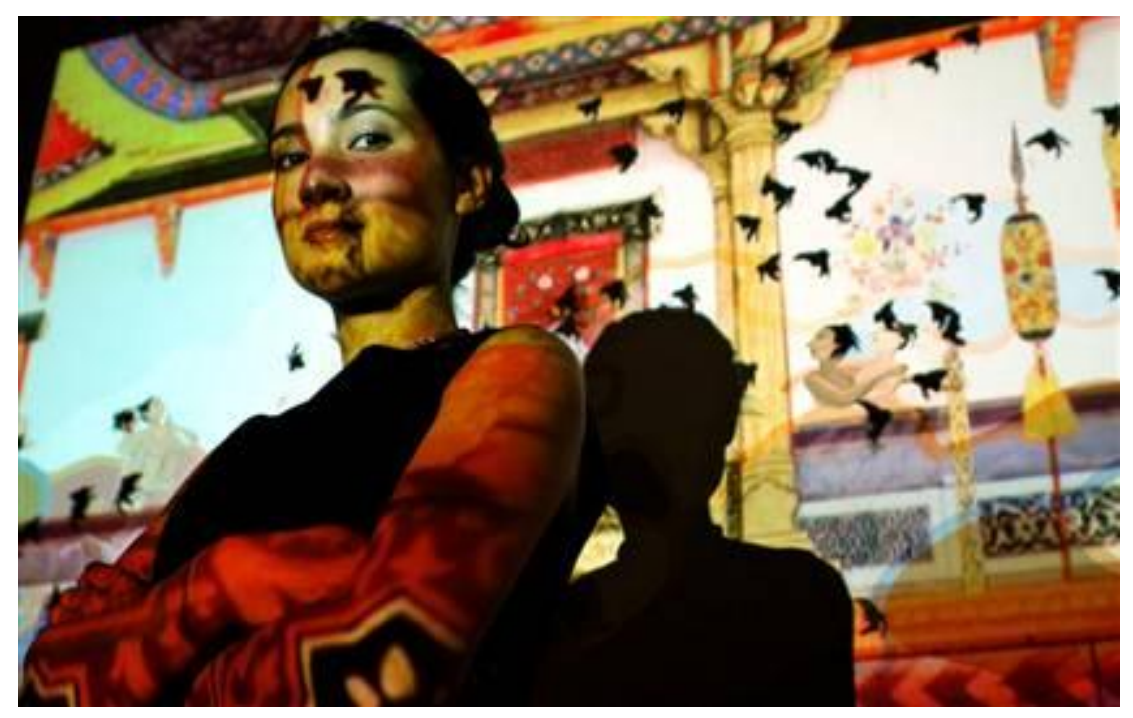

الفنانة شازيه اسكندر داخل أحد عروضها الفنبة

نشأت كفنانة مسلمة في لاهور تستكشف من خلال أعمالها التكامل بين ثقافة المسلمين وثثافة الهندوس من

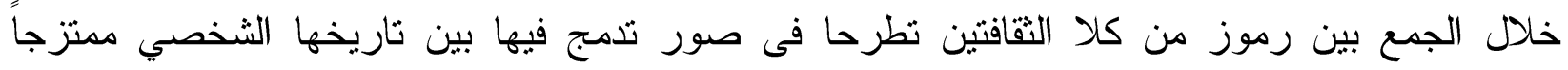
بقناعتها الفكرية و الدينية وتناقش أيضاً العلاقة بين السلطة و والجنس و المعتقد .

ويعتبر الدين هو العنصر الأكثر إثارية فى تجربتها الفنية وحياتها الثخصية أيضاً كفنانة مسلمة فهي

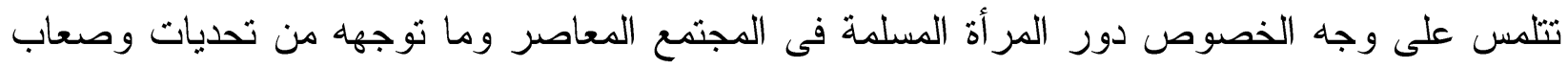
إزاء وجهة النظر الغربية النى قرنت مابين الإسلام والإرهاب واضطهاد المرأة ، تعمل شازية على تحفيز 
الذاكرة البصرية لجمهورها من خلال إضافة عناصر معاصرة إلى حقل بصري تقلبدي وهو المنمنمات الإسلامية وهي تحاول من خلال ذلك أن تجبر مُشاهدها على التوفيق بين مشاعر متضاربة مخبأة داخل المناظر الطبيعية الخلابة للمنمنمات ، فضلا عن تقديم مجموعة كبيرة من مفردات العالم الإسلامي التقليدي

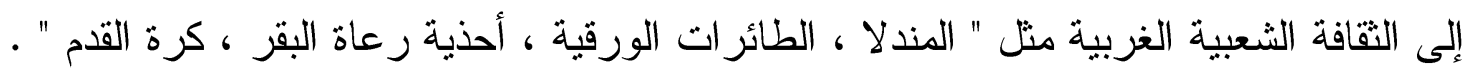

شازيا اسكندر لا تطرح أفكار ها من خلال أعمال مسطحة فقط بل تخلق أجواءاً تركيبة تجمع بين عدة

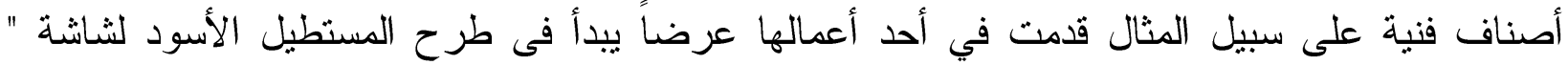
اللابتوب " الخاص بها و ومنه ينطلق المشاهد إلى ساحة تتراكم فيها علامات سوداء غير منتظمة ونستكشف أن هذه العلامات التى تبدو كأشكال ظلية غير منتظمة هي في الأصل شكل تسريحة الشعر

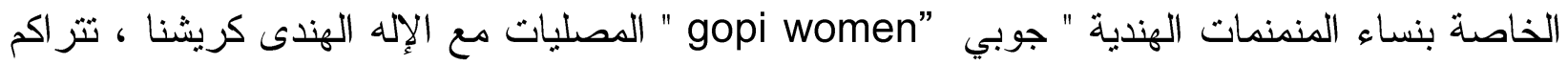
تلك الأشكال وتختفي هيئات النساء وتتخذ شكل أسراب الطيور والخفافيش كأنها تتوعد غزاة ة تلكك الإمبر اطوريات العتيدة ـ وقد دأبت الفنانة على توليد التوقعات الجديدة لمفرداتها البصرية و واستعانت ببر امج الكمبيوتر التى سمحت لها بالتحرك أدائياً وفق طبقات متعددة ومتر اكبة تتيح لها حرية ومرونة في

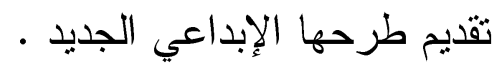

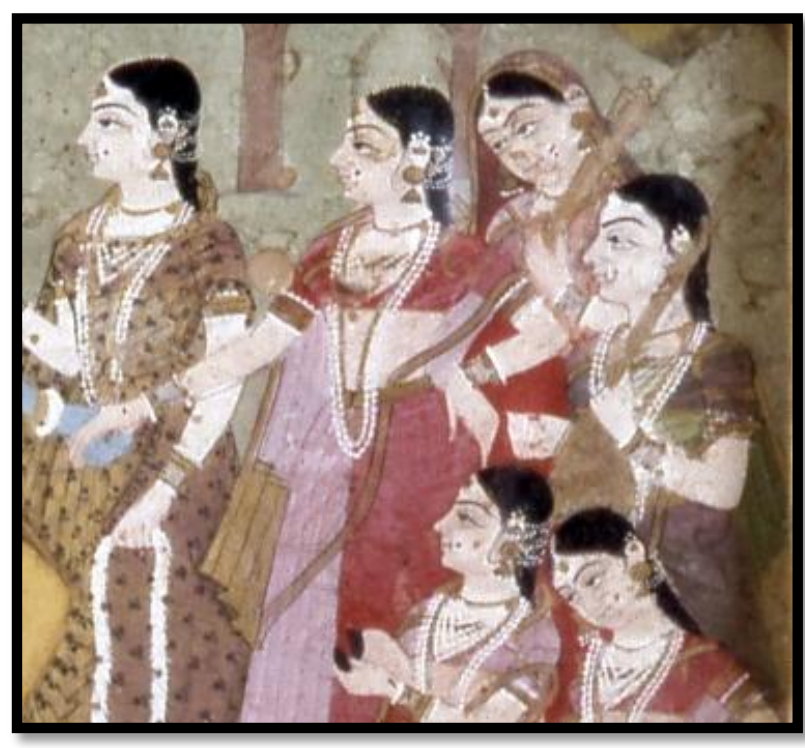

تفصيلية من العمل السابق توضح شكل تسريحة الشعر

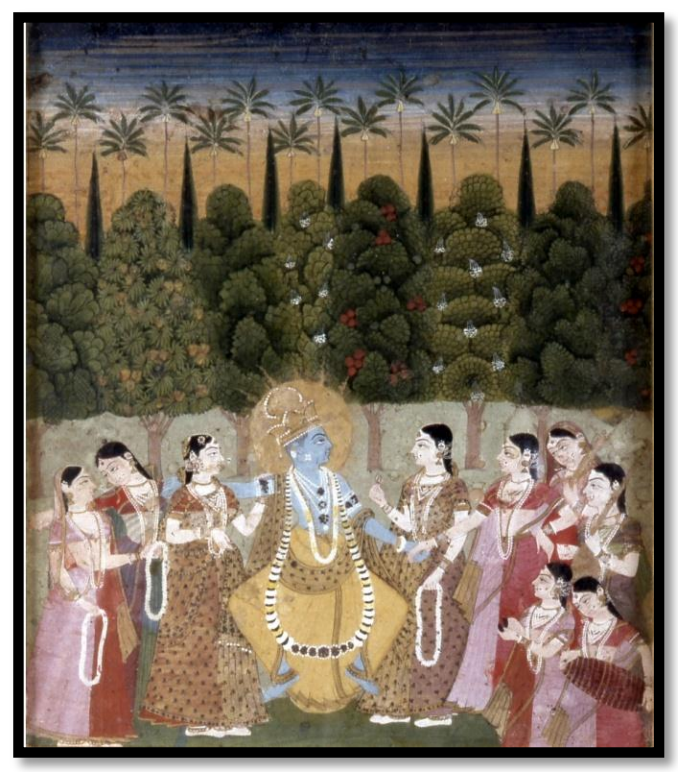

كريشنا يرقص مع نساء جوبى ق1/ 


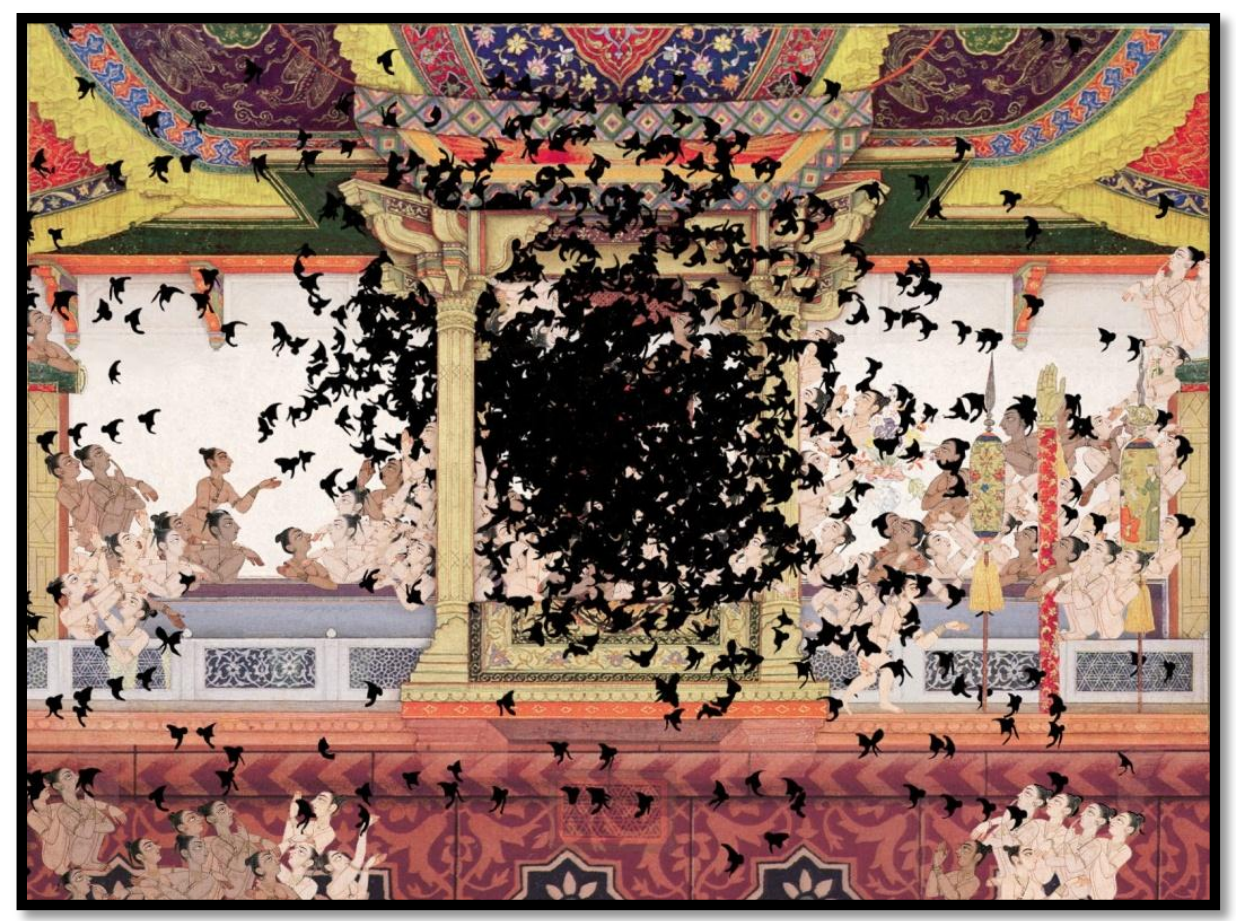

شازيه اسكندر

(AmeSea Data Base - ae - Jan. 2015- 0006) 
و الفنانة مولعة بهذا الثكل الظلى الذي مثل لها مفردة حيوية وأساسية ومثيرة فى أعما لها واستخدمته فى العديد من أعمالها التزكيبة وهي تؤكد حرصها على ألا تنزعه من سياقه الأصلي أو مكانه الذي أتي

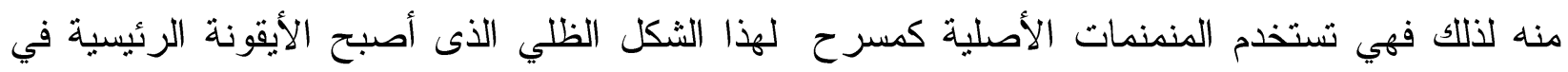

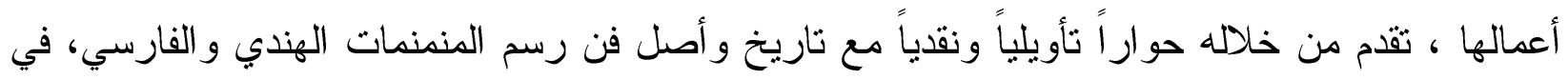
الوقت نفسه الذي تفحص فيه الحدود السياسية و التقافية كفضاء للحوار و التحليل .

من هنا كان الأساس فى تجربة شازيا هو تللك السلاسة التى تقدم بها تصورها عن التحولات الجديدة في طر ائقا للرؤية وكأنها تجعلنا نرى الأشياء للمرة الأولى ، وهئ هونى تعمل جاهدة على تقديم نهايات مفتوحة لأعمالها ولديها ذلك الفكر الثاقب الذي برصد بوعي العلاقة المعقدة بين وطنها الأم " باكستان" و الوطن

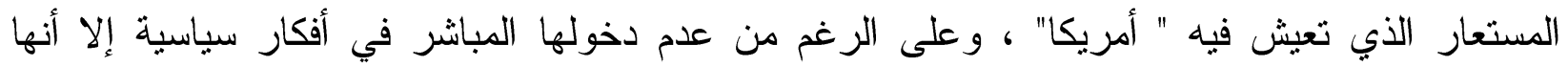

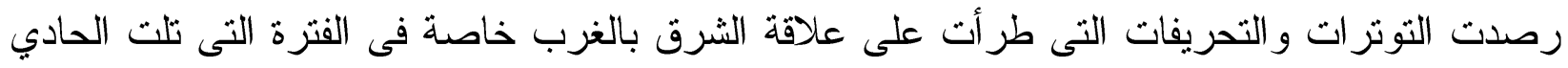
• عشر من سبتمبر

وفى إطار ذلك تهنم شازيا بالناحية المفاهيمية التى توجزها في البحث في المسافة بين النص البصري الأصلي وبين التزجمة الجديدة له فى سياق معاصر ، فجميع أعمالها من المنمنمات حتى الأعمال

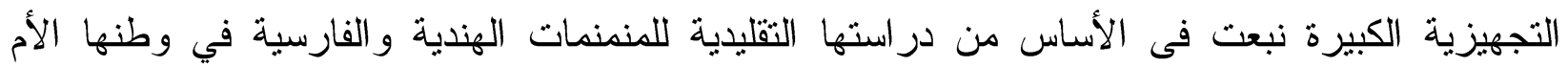
لاهور التى استقطبتها للوقوع تحت سطوة هذا الجمال الأخاذ للمنمنمة لتستكشف من خلالها علاقات بصرية جديدة ولتقتص هذا الثكل المفضل لها لتصيغ منه عو الم تجربتها المعاصرة فبالانتقال إلى الدرسة فى الو لايات المتحدة الأمركية استكشفت الطريق إلى تفكيك مفردات المنمنمة وخلق تلك الصور الهجينة التي تحاول أن تطمس من خلالها تلك الثنائيات أو التناقضات بين: الهندوسي و المسلم ، التقليدي و المعاصر ، الثرق و الغرب ، التمثيلي و التجريدي ـوماز الت للأن تشارك فى العروض العالمية الكبيرة

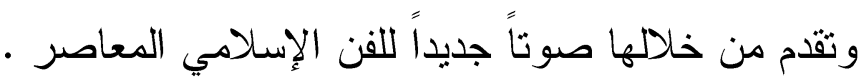


فنانة إيرانية ولات في طهران 1900 ، ونشأت وتعلمت في "هيوست ـ تكساس" ، من خلال التصوير الفوتوغرافي والأعمال التركيبية تستكثف سودي الصراع بين الفضاء العام والفضاء الخاص عبر المزواجة بين المفاهيمي والتقتي فتقدم صوراً تثير إلى مستويات متعددة من القراعة لثقافتين مختلفتين لكنها تطرح قضيتها مقترنة بأجنحة من الخيال والحساسية الفائقة.

التناقض هو المقولة الرئيسية التي تطرحها سودي شفيق بين الخلفية الثقافية للقنان المسلم وبين العضارة الأمريكية المعاصرة ، هي تقدم خدعة الواقع من خلال الصور التى تقدمها وسائل الإعلام ، ومن خلال ذلك تستكثف التوتر القائم بين المساحات الخاصة والعامة متحفظة على تلك السناريوهات الإعلامية الزائفة التى تقدم الصور النمطية للثقافة الإسلامية من خلال التركيز الضيق على بعض المظاهر السطحية التى تثوه صورة الإسلام .

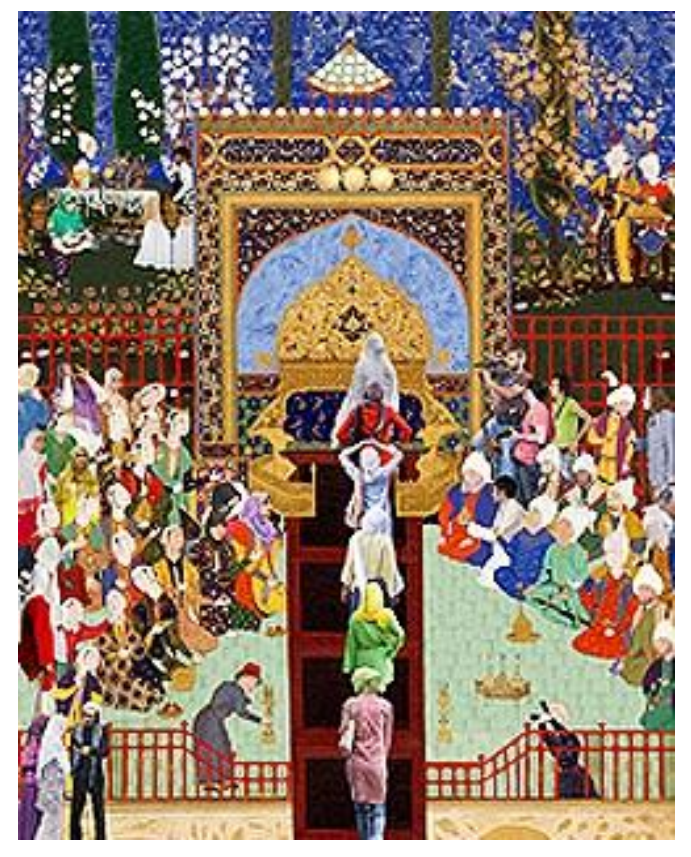

سودي شريفي 
وقد تعزل سودى عناصر المنمنمات فتضعها على خلفية لونية مسطحة في فضاء خال من أي علامات تقود لزمان أو مكان بعينه مستعينة بعائلة لونية معاصرة بعيدة عن الخلفيات اللونية الأصلية للمنمنمة التقليدية وتجعل هذا الفضاء المعاصر مجالا تجمع فيه بين شخصية معاصرة وشخصية خارجة من قلب المنمنمة الأصلية فتجعنا نتأملهما معاً بشروط بصرية وفكرية جديدة .

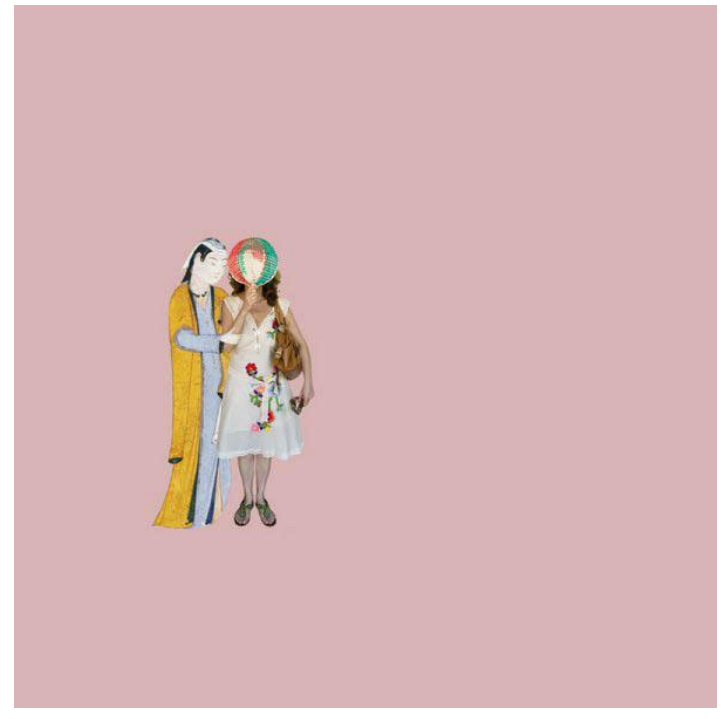

سودي شريفي

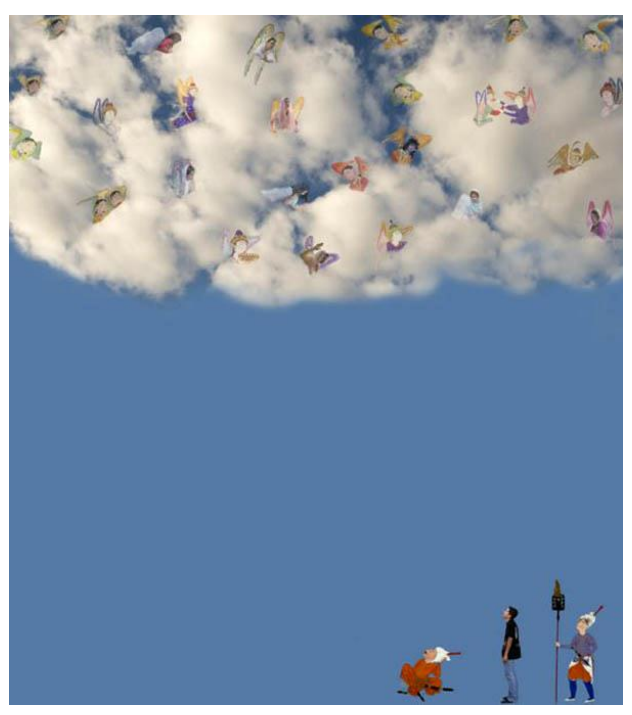

سودي شريفي

و هي تأمل أن يتحدى المسلم هذه التوقعات الضيقة التي يضعه فيها هذا المنظور الانتقائي المحدود الذي تقدمه وسائل الإعلام عن صورة المسلم ، وباستخدام الزائف والحقيقي تحلق سودي فى أعمالها مابين الو اقعية الفوتوغر افية و الخيال في تلك الحالة الغرائبية التي تضعنا فيها ـ

في مجموعة الفنانة " سلسلة المسرات الفارسية " تضيف الفنانة إلى المنمنمة التقليدية عناصر معاصرة تزرعها بين تفاصيلها فتعيش مع مفرداتها لدرجة أننا قـ لالثحها للوهلة الأولى ونراها كجزء من مفرداته و نقع فى هذا الخلط والإلتباس بين عالمين متناقضين ، ثم ما نلبث أن نكتثف الخدعة حين نقترب ومن ثم نكتسب انتباهاً جديداً نحو العمل ويبدأ عقلنا فى تساؤلاته . 


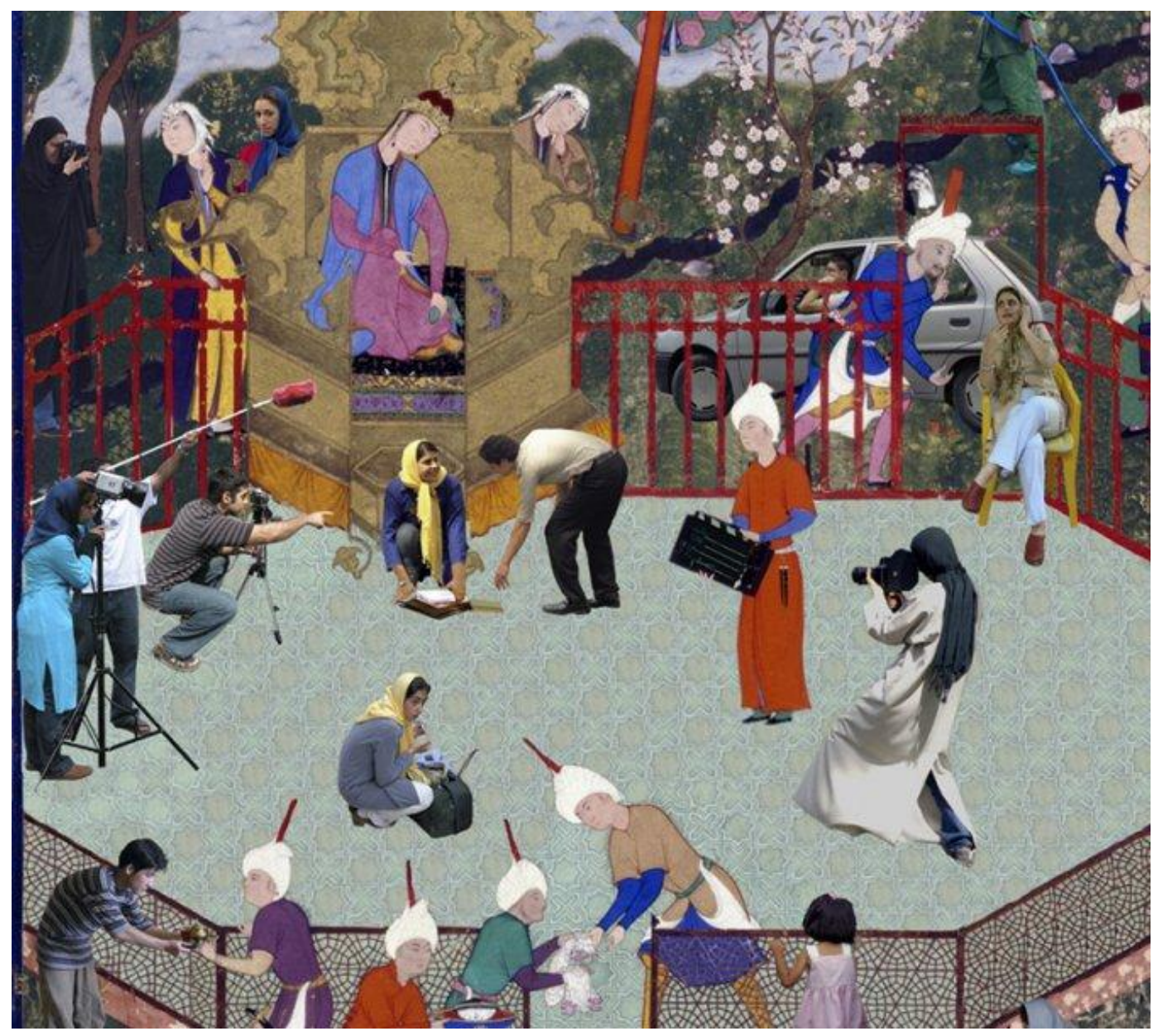

سودي شريفي

(AmeSea Data Base - ae - Jan. 2015- 0006) 
وفى مجموعة المسماة : " الصحراء التى تقع خلف المدينة تخصني " تضمن الفنانة قضاياها المعاصرة في لوحات المنمنمات التقليدية عن طريق الكولاج الفوتوغرافي و إدراج التفاصيل المعاصرة في الخيال التاريخي ، هي تحاول أن تخلق قصص جديدة فتصور الحياة اليومية الإيرانية وتسلط الضوء على

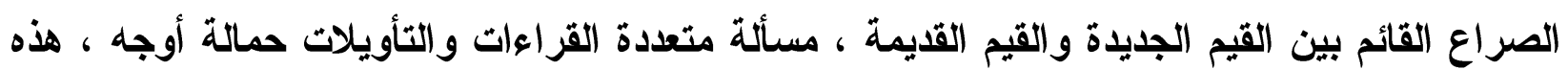
المجموعة تقلم فيها نماذج من شخصيات مصغرة تعيد النظر في تفاعلها بين المعاصرة والتأريخية بدلا من جلب عناصر معاصرة وإخخالها إلى المنمنمة كما فعلت في سلسلة المسرات الفارسية ، فهى في هذه المرة تقوم بإخراج شخصيات المنمنمات من مكانها وسياقها الأصلي لتضعها في سياق الحياة المعاصرة وتعيد إحيائها في ظروف جديدة ، تماما كأننا نختبر أفكارنا التقليدية في إطار الحياة المعاصرة كيف لها أن تعيش وتثمر وتطل علينا برداء جديد .

إنها تستعير الثخصيات الصغيرة من المنمنمات الفارسية تكبرها وتصطببها في رحلة إلى الحياة الإيرانية المعاصرة فتصورها محاطة بمحيط البيئة المعاصرة باعتبارها مزيج من المفارقات و المتناقضات التي تنبع من ثقافة المنطقة ، هي تحكي قضية الحياة الثقافية والسياسية الإيرانية المعاصرة التى تجسد من وجهة نظرها التناقض بين ثقافة المنطقة والدين ونظام الحكم فى أعمال خرجت متأثرة بالحركة الاحتجاجية التى نشأت فى أعقاب انتخابات الرئاسة عام 9 . . ب ، وهي الحركة التى جلبت إلى السطح ذلك التناقض الكامن تحته .

تطرح تساؤلها : كيف تكون البلاد جمهورية ديمقراطية ومسئولة أمام مواطنيها في وفي الوقت نفسه تدعي أنها دولة ثيوقراطية خاضعة لمساعلة " كائن أعلى" وهي تقلم ذلك التساؤل كأحد القضايا المعاصرة المثيرة للجدل . وهكذا من خلال لحظات خاصة وقصص خاصة تتعلق سودي بالمعاصرة بينما شخوصها وأجوائها تتعلق بالماضي •

ومن خلال هذا تطرح سودي شريفي حضوراً جديداً للفن الإسلامي من خلال استدعاء أحد أهم أيقوناته وهي المنمنمة الفارسية لتصدح بقضايا معاصرة . 


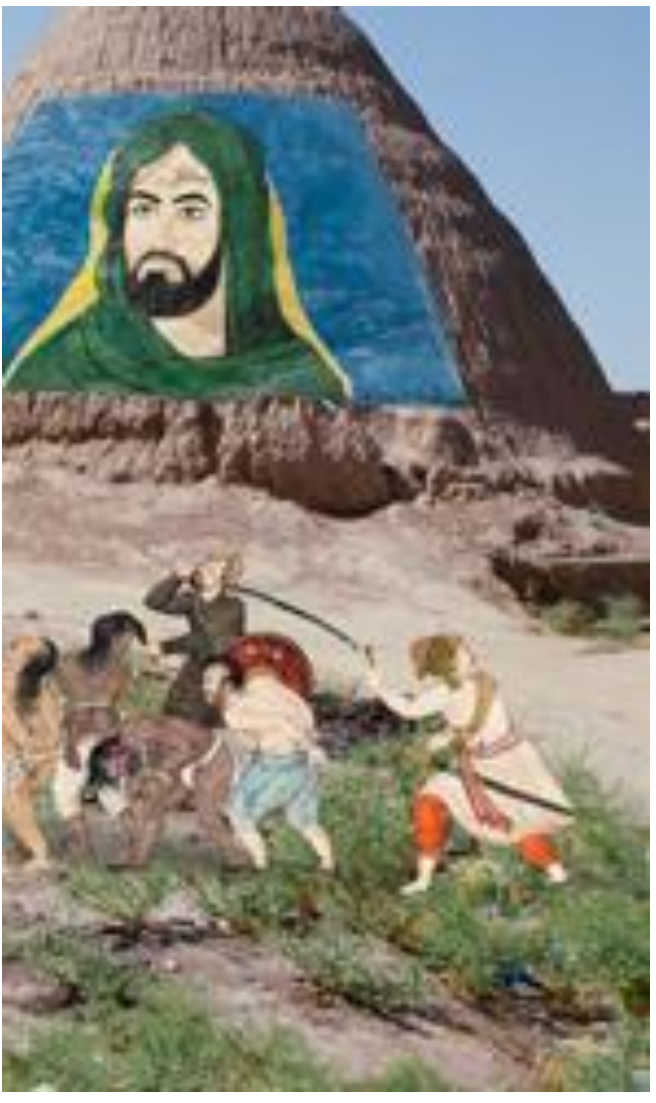

سودي شريفي

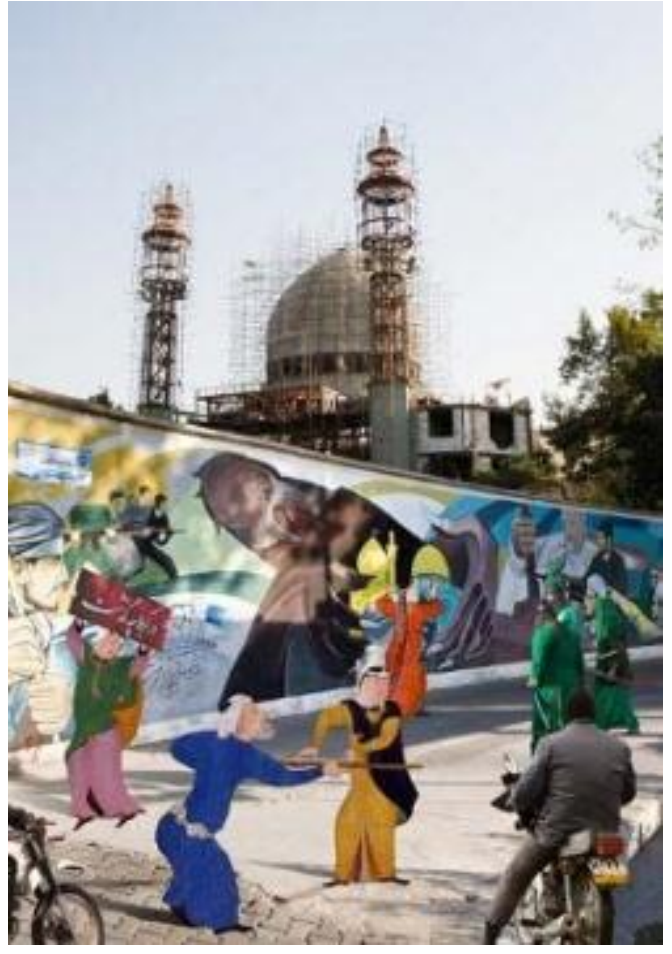

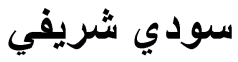




\section{محمد أبو النجا 197}

نلمح فى تجربة الفنان المصري محمد أبو النجا ( . 9 ( ) ) مداخل تجريبية مختلفة وهو يعد نموذجـاً للفنان المعاصر دائم البحث ، وقد تضدنت أحد مباحثه فكرة التراث الشرقي بشكل عام من خــلاد عـدة تجارب مثل : " انعكاسات ، سجادة إير اني ، كتاب الأسرار ، الاستشر اق ، كاما سوتر ا " • إنه يبحث عن صيغ معاصرة من خلال تاريخ الفن ، صيخ قادرة على حمل انشغالاته كفنان معاصر يبحث فــى التـابو الثلاثي " الجنس ، السلطة ، الدين "

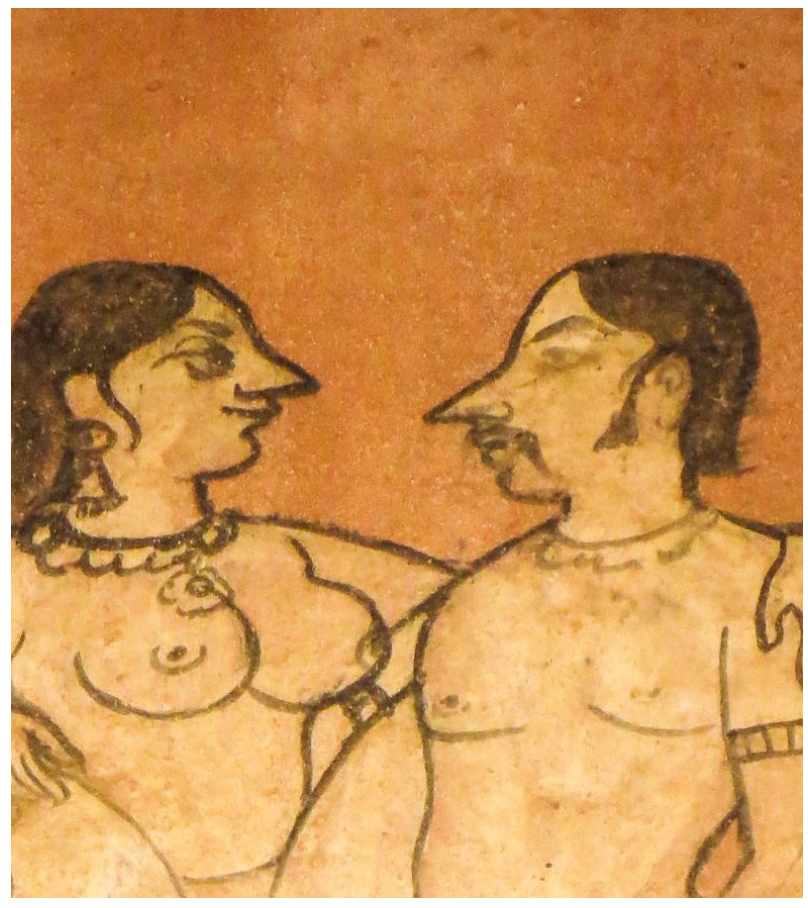

تفصيلية من المخطوط الهندي " كاما سوتر I"

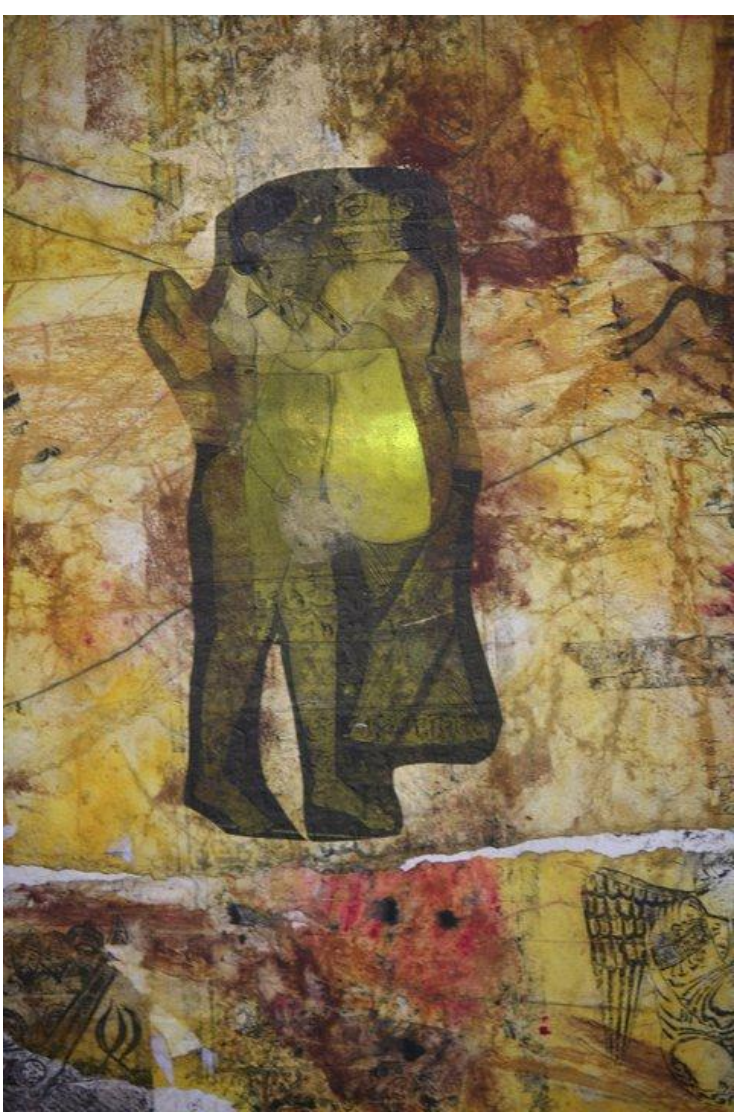

عمل للفنان محمد أبو النجا 
وهو فى ممارساته كمصور لا يقنع بمسطح هادئ محايد ينقله من سكون لسكون؛ بل يعمد أحياناً لأن يزيد

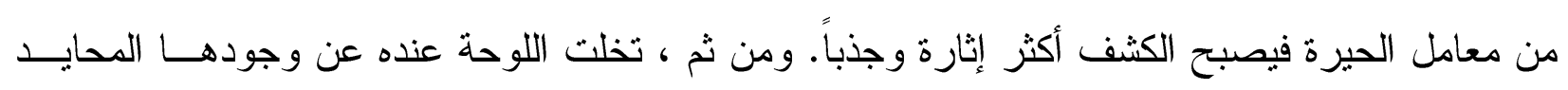
الدسالم ومظهر ها الصالوني التزييني؛ ودخلت مساحة للثغب و الأخذ و الرد و النهايات المفتوحسـة. و فــي إحدى تجاربه التى ندن بصددها الأن يدخل إلى نسيج أعماله رقائق فوتوغر افية من مخطوطات شـرقية و إسلامية قديمة قد تحوي معادلات حسابية أو رموز سحرية أو رسوم علمية لــلات متخيلــة أو دوائــر وتروس أو مصفوفات من الكتابات أفقية ور أسية ومائلة تتخذ إيقاعاً بصرياً يتحرك كخلايا كائنات دقيقــة تنمو في اتجاهات عديدة . 


\section{عمل للفنان محمد أبو النجا}
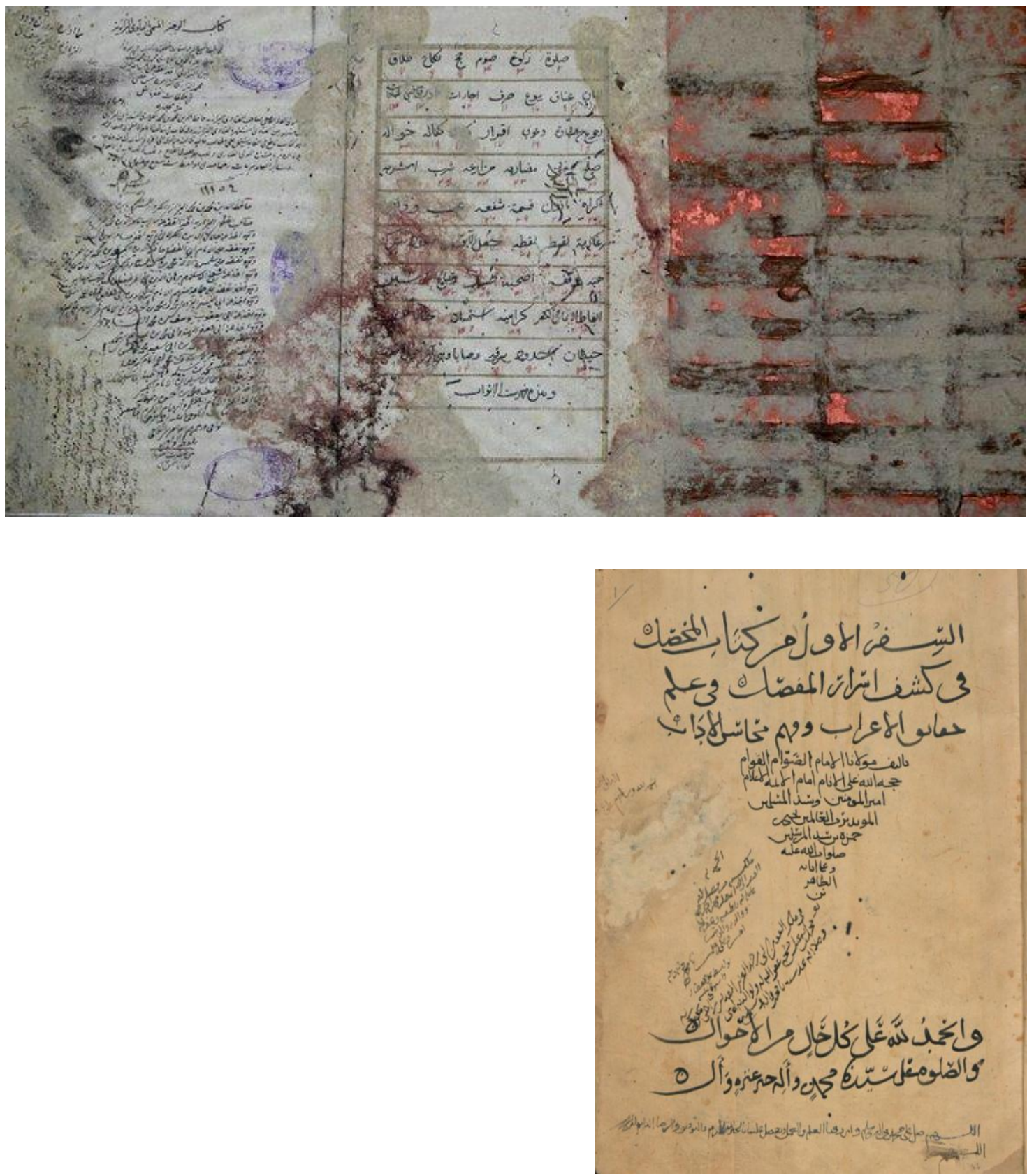

من مخطوط " المحصل في أسرار المفصل 


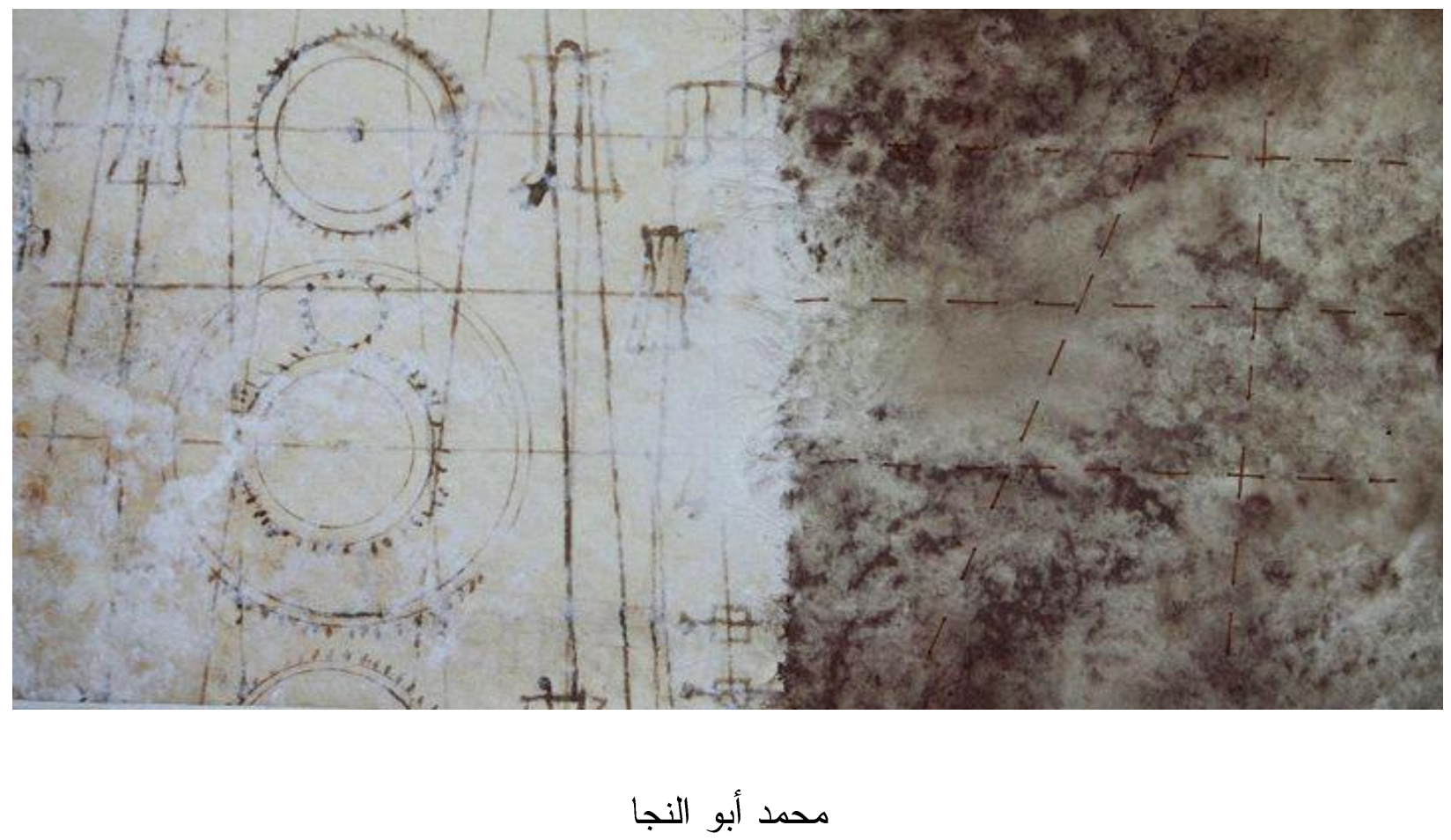

(AmeSea Data Base - ae - Jan. 2015- 0006) 


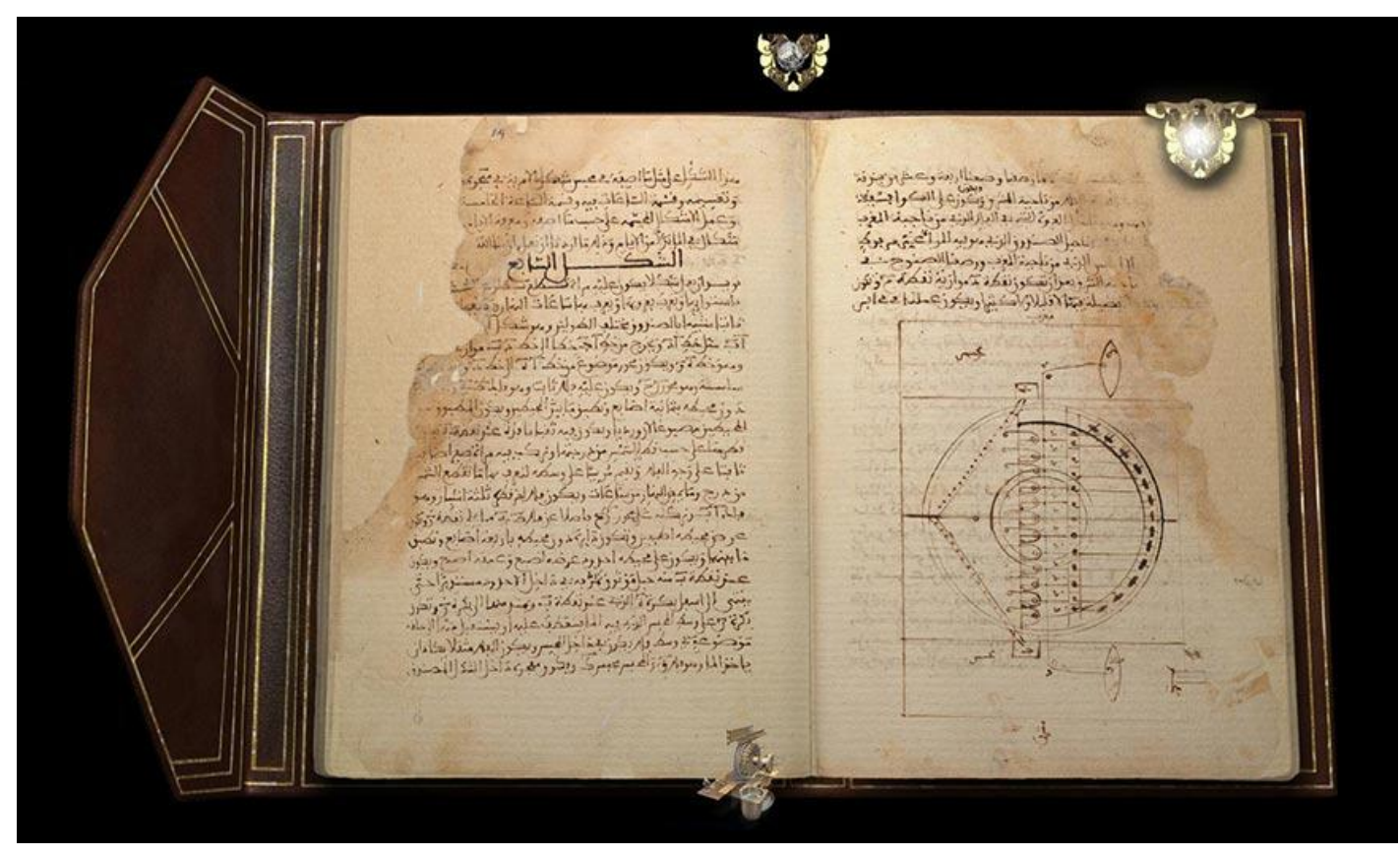

مخطوط كتاب الأسرار

وأحياناً أخرى نجد كتابات عربية في خلفيات هادئة نلمس بصعوبة حضور ها الخافت ـ هـــه المفـردات تتدمج مع مسطحه التجريدي الذي يحتفي فيه بقيمة الملامس القديمة والأسطح التى توحي بأنفاس التاريخ وتر اكم آثار الزمن ، يغمرها الفنان بغلالات من اللون الثفاف ورقائق الورق المعالج يدويا ليوحي بالقدم و التهلهل و التآكل ، ويدع الفنان تأثرات التبقيع و الكشط و الحذف و الإضافة تجري عملها على السطح بأكمله فيصنع لهذه المفردات تاريخ مشترك مع خلفياته التجريدية ، إنه يستحضر تاريخها الخاص ويوحدها مــع تاريخ عمله الفني الذي يجتاز فيه رحلة بناء اللوحة بمنعة بادية .

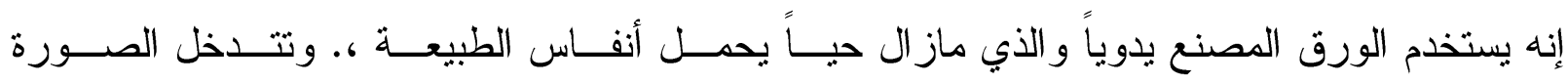
الفوتوغر افية في منح اللوحة بعداً إيهامياً لنعيد رؤية العمل بهاجس جديد ؛ محاولين أن نربط تلك المفردة (AmeSea Data Base - ae - Jan. 2015- 0006) 


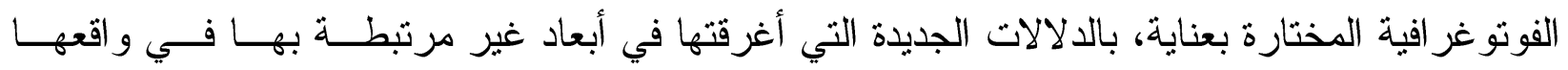
التاريخي • ورغم اختلاف مشارب تلك الخامات و الأشياء إلا أنها تعيش معا حياة جديدة بقوة طاقة الفنان التي تلملمها وتجعلها ممكنة كعائلة واحدة متصلة النسب.

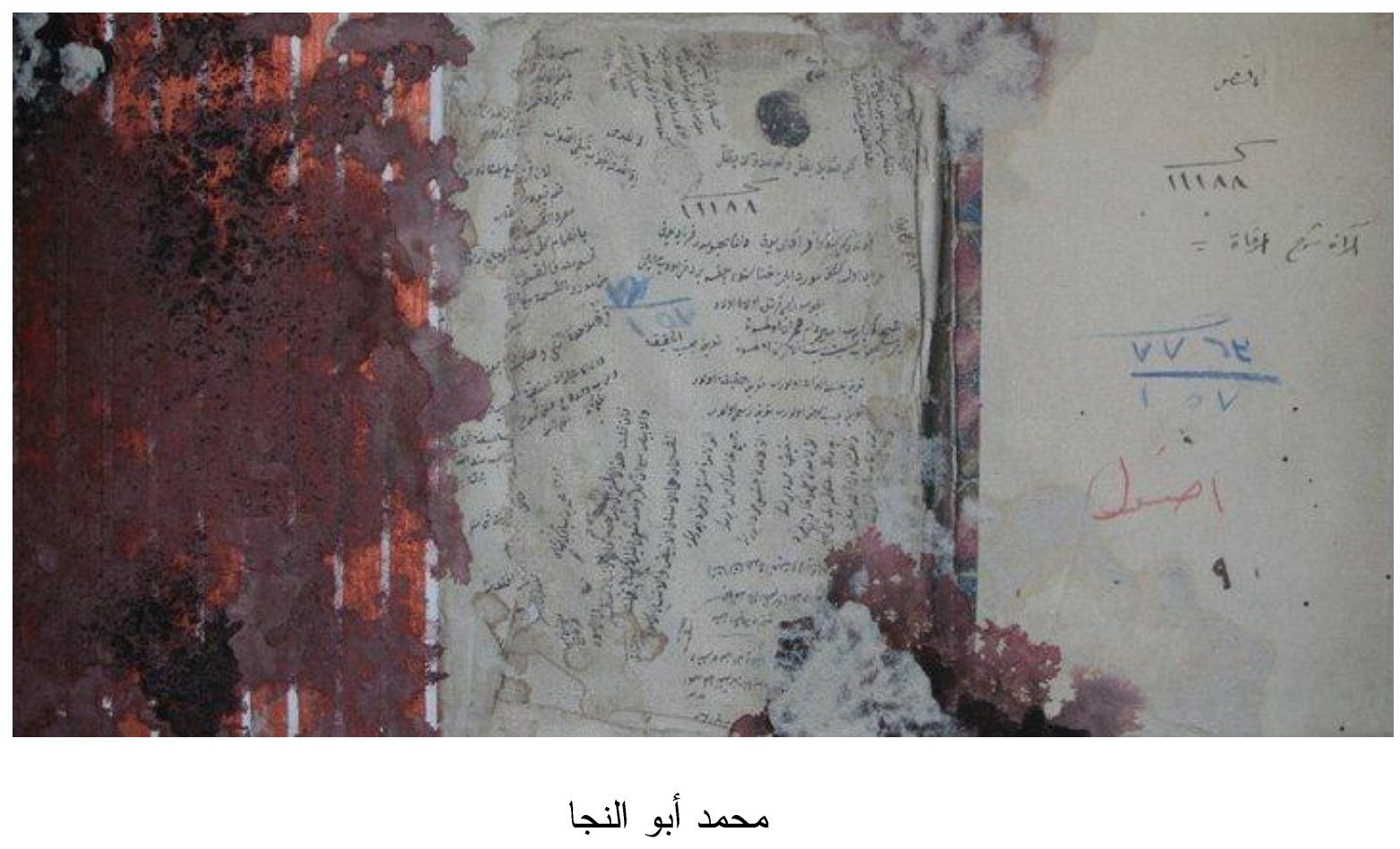




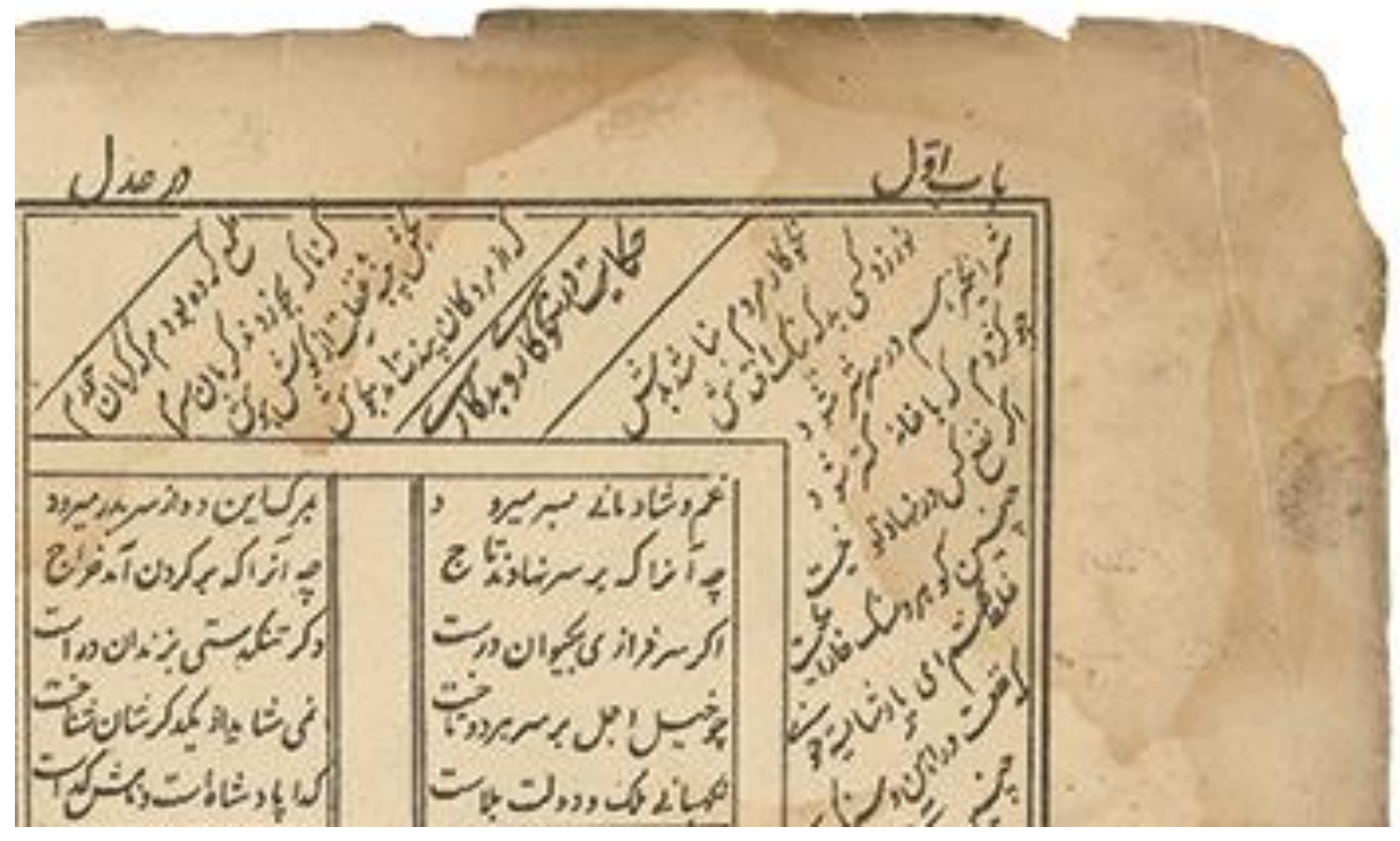

من مخطوط عربي قديم

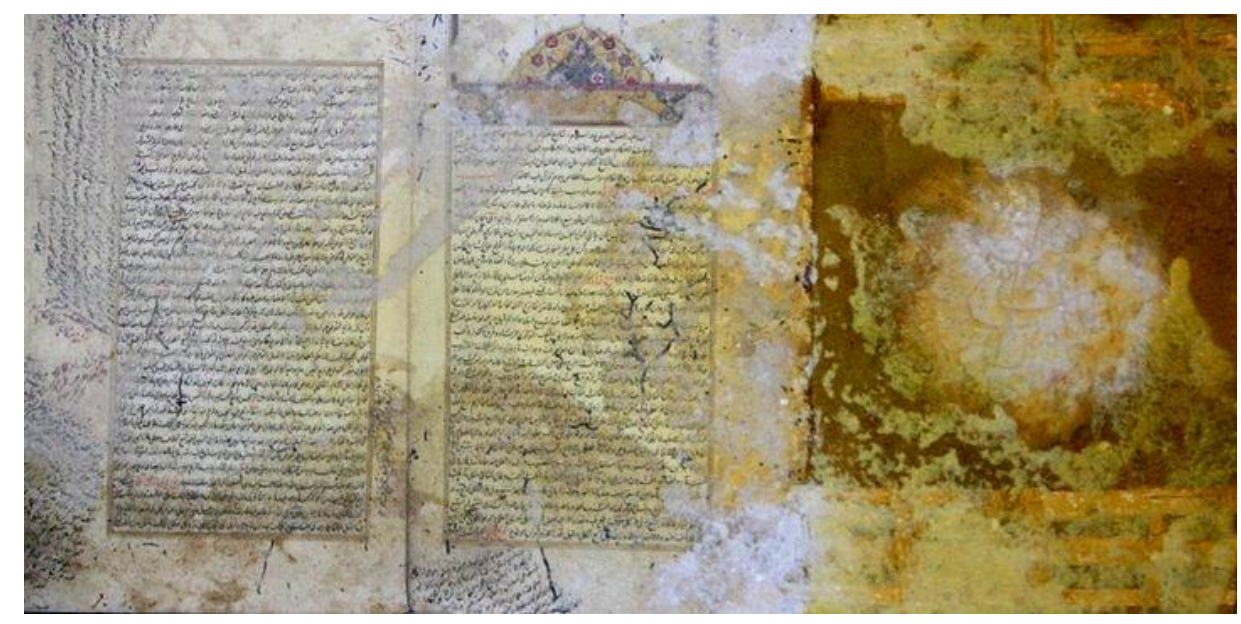

محمد أبو النجا 


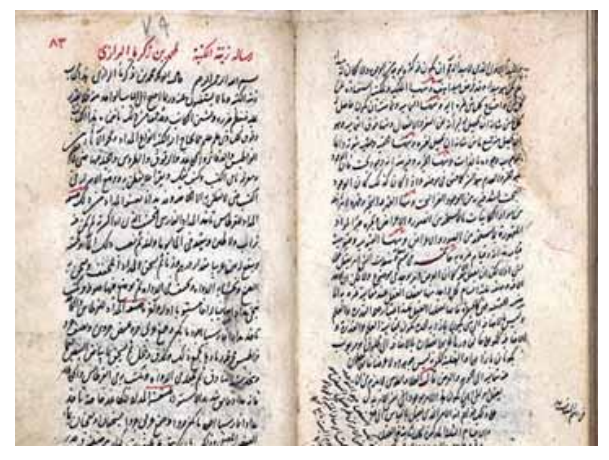

من هذا النسيج يتولد في أعمال أبو النجا حضورًا جديداً للفن الإسـامي عبر حالة ضبابية غيـر مباشــرة يسرِّب لنا الفنان من خلالها دفقة من الأحاسيس المبهمة على الرغم مــن ارتباطهـــا بــبعض المفـردات التاريخية و التز اثبة إلا أنها انتزعت منه ووضعت في سباق جديد ، و هذا التلميح في ذاته بفتح درباً لتدفق الصور وتداعيها.

•وفي النهاية وسيقى الفن الإسلامي يمثل شكلاً مهماً من أثُكال الفكر الجمالي القادر علـى التو اصل ليثري التجربة الفنية المعاصرة بأطروحات جديدة . 


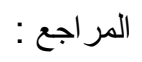

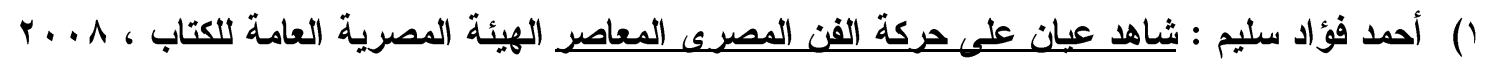
r

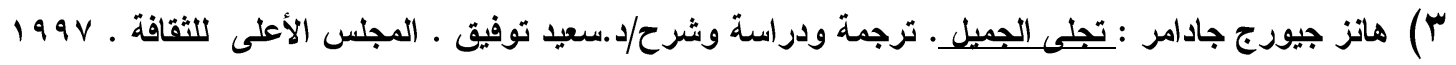

ع) طونى مارينى : اسهامة الجمالبة العربية فى نشأة الفن الغريحى العلبث ترجمة حسن الكاظم ، مجموعة دراسات صدرت عن معهد العالم العربى ، باريس 